\title{
UČENIČKE ZADRUGE KAO RASADNIK ZADRUGARSTVA? REFLEKSIJE ZADRUŽNIH NAČELA U DJELOVANJU UČENIČKIH ZADRUGA U HRVATSKOJ
}

\author{
Davorka Vidović
}

Fakultet političkih znanosti Sveučilišta u Zagrebu Lepušićeva 6, 10000 Zagreb e-mail: davorka.vidovic@fpzg.hr

\begin{abstract}
Sažetak
Učeničke su zadruge fenomen s dugom tradicijom u Hrvatskoj, a od 50-ih godina 20. stoljeća formalno su regulirane kao oblik izvannastavnih aktivnosti unutar odgojno-obrazovnog sustava. U zadnjih 15 godina broj se učeničkih zadruga značajno povećava te ih danas ima 602 što znači kako gotovo polovina škola ima osnovanu učeničku zadrugu. U radu su predstavljeni rezultati istraživanja o učeničkim zadrugama u Hrvatskoj, koje je provedeno 2018. i 2019. Istraživanje je temeljeno na eksplorativnom pristupu i kvalitativnoj metodologiji, a i koristili su se intervjui i fokus grupe na prigodnom uzorku od deset učeničkih zadruga. U radu je, kao glavni konceptualni okvir, koristen pristup Medunarodnog saveza zadruga (ICA) koji u odredenju „zadružnog identiteta“ navodi definiciju, sedam temeljnih načela i deset vrijednosti. Svrha je rada bila utvrditi na koji način se temeljna zadružna načela primjenjuju u djelovanju učeničkih zadruga te na koji ih način možemo promatrati kao rasadnike zadrugarstva. Rezultati istraživanja pokazali su kako se neka načela, poput edukacije o zadrugarstvu i demokratsko upravljanje, nedovoljno reflektiraju u radu učeničkih zadruga. To u konačnici može slabiti razvoj zadružnog identiteta kod učenika te smanjiti njihov interes za pokretanjem ili sudjelovanjem u zadruzi u odrasloj dobi.
\end{abstract}

Ključne riječi: obrazovanje, škole, učeničke zadruge, zadruge, zadružna načela, zadružni identitet

\section{UVOD}

Učeničke su zadruge slabo istražen fenomen koji predstavlja specifičan oblik zadrugarstva. Dio su hrvatske povijesti zadrugarstva već oko 150 godina, a danas čine dio odgojno-obrazovnog sustava. Učeničke zadruge model su praktičnog učenja i razvoja poduzetničkih vještina i demokratskih kompetencija kroz proizvodnju, timski rad, i upravljanje poslovanjem, a temelji se na vrijednostima suradnje, solidarnosti te brizi o zajednici i okolišu. Učeničke su zadruge povezane sa zadružnim sektorom na način da dijele isti način djelovanja i iste vrijednosti. Međunarodni savez zadruga (engl. International Co-operative Alliance - ICA) 1995. odredio je skup definicija, načela i vrijednosti koji čine „zadružni identitet" - temelj koji bi trebali poštovati svi modeli zadruga širom svijeta. Ovaj su model usvojila mnoga nacionalna zakonodavstva, među njima i hrvatsko zakonodavstvo 2011., čime se približilo europskim i globalnim standardima. 
Namjera je ovog rada pokušati utvrditi na koji način se zadružna načela primjenjuju i reflektiraju u djelovanju učeničkih zadruga te može li se i na koji način učeničke zadruge gledati kao rasadnike zadrugarstva. Rad čini nekoliko poglavlja. U prvom dijelu iznesena su određenja učeničkih zadruga i srodni koncepti te određenje koncepta zadružnog identiteta, koji je poslužio kao tematski okvir za analizu učeničkih zadruga u empirijskom dijelu. $U$ drugom dijelu pružen je pregled različitih pristupa u istraživanju o učeničkim zadrugama. Treći dio pruža uvid u povijesni i suvremeni kontekst razvoja učeničkih zadruga u Hrvatskoj. U trećem dijelu opisana je metodologija empirijskog istraživanja. Četvrti dio daje prikaz rezultata tematske analize i diskusiju oko načina na koji se u djelovanju učeničke zadruge odnose prema svakom zadružnom načelu. U zaključcima se ukazuje na pozitivne refleksije nekih od ovih načela u praksi učeničkih zadruga, kao i na glavne probleme u njihovom djelovanju.

\section{UČENIČKE ZADRUGE}

\subsection{Odredenja i srodni pojmovi}

Učenička zadruga (engl. school cooperative; franc. cooperation scolaire) u Hrvatskoj se definira kao „dragovoljna interesna učenička organizacija, koja pridonosi postizanju odgojno-obrazovnih i društveno-gospodarskih ciljeva škole / ustanove, jer kao oblik izvannastavne aktivnosti učenicima/ama omogućuje stjecanje radno-tehničkoga, ekološkoga, gospodarskoga, društvenog i etnoodgoja i obrazovanja te razvoj sposobnosti i korisno provođenje slobodnog vremena" (HUUZ, 2019b). Učeničke zadruge u $\mathrm{Hr}$ vatskoj djeluju kao dio odgojno-obrazovnog sustava i to kao izvannastavna aktivnost orijentirana na radno iskustvo i proizvodnju. Uobičajeno postoje i djeluju u okviru osnovnih i srednjih škola, no mogu djelovati i u sklopu drugih odgojno-obrazovnih ustanova, poput centara za odgoj i obrazovanje za mlade s posebnim potrebama ili prema posebnim programima, učeničkih domova te fakulteta.

Literatura koja tematizira učeničke zadruge, dotiče se i drugih srodnih koncepata, poput zadružnih škola, mini-kompanija ili školskih kompanija, zadružnog obrazovanja te obrazovanja za poduzetništvo, što otežava detektiranje sličnosti i(li) razlika u konceptu i pristupima učeničkom zadrugarstvu u različitim zemljama. Primjerice, u SAD-u postoji koncept zadružnog obrazovanja u srednjoškolskom sustavu još od ranog 20. stoljeća (Keats, 1950:3). No, ovaj se pojam razumije kao oblik strukovnog obrazovanja, tj. model koji kombinira klasičnu nastavu i učenje kroz praktično radno iskustvo, s ciljem brzog osposobljavanja učenika za proizvodni ili uslužni rad, a ne nužno kao model učenja koji se temelji na zadružnim načelima. Prema rijetkim dostupnim zapisima iz prošlog stoljeća, razvidno je kako je koncept učeničkih zadruga u nekim zemljama bio utemeljen na zadružnim načelima i djelovao kao rasadnik zadrugarstva. Tako Meyering opisuje uvođenje učeničkih zadruga u srednjoškolski obrazovni sustav u Turskoj kao „ozbiljni projekt“ turske vlade na snazi još od 1942., kojim je poticala sve srednje škole na osnivanje svoje učeničke zadruge (kooperative) u skladu s lokalnim uvjetima i potrebama (Meyering, 1948:235). Kao glavni ciljevi školskih zadruga navode se: razvoj međusobnog uvažavanja među članovima, 
promoviranje prodaje lokalnih, prirodnih proizvoda nasuprot uvozu luksuzne robe te reinvestiranje dobiti za opće dobro. Prema Mayeringovim opisima, učeničke zadruge funkcionirale su na dobrovoljnom članstvu, i različitim početnim ulozima članova (s obzirom na mogućnosti) te na demokratskom upravljanju prema načelu jedan član-jedan glas, bez obzira na visine početnih uloga (Meyering, 1948:235-236).

Zadruge su, pa tako i učeničke, $s$ usponom neoliberalne ekonomske politike od osamdesetih godina prošlog stoljeća, počele padati u zaborav, tj. „izašle su iz mode“ (Manse1l, 2011). Prema studijama u nekim zemljama, primjerice Njemačkoj, od devedesetih je uočen trend razvoja škola s poslovnom (biznis) orijentacijom (Liebel, 2009). No, od početka dvijetisućitih za učeničke zadruge ponovo počinje rasti interes, posebno u okviru raznih (novih) koncepata i politika, poput obrazovanja za poduzetništvo, za socijalnu ekonomiju ili za održivi razvoj.

U nekim zemljama, poput Njemačke ili Norveške, na učeničke zadruge gleda se kao na jedan od oblika mini ili školskih poduzeća (Odegard, 2007; Liebel, 2009; Hytinkoski, 2012; Göler von Ravensburg, 2017). Učeničke se zadruge u ovim zemljama javljaju relativno nedavno i njihov rast vezan je uz spomenute koncepte obrazovanja za poduzetništvo (ili društveno poduzetništvo) i obrazovanja za održivi razvoj. ${ }^{1}$ Od 2006. u Njemačkoj se širi ideja kako se školska poduzeća trebaju preoblikovati u zadruge, točnije u učeničke zadruge, jer su one svojim vrijednostima bliže ciljevima obrazovanja za održivi razvoj. Na zadrugu se gleda kao na organizacijski oblik koji može pružiti učenicima (i nastavnicima) iskustvo održivog društvenog poduzetništva utemeljenog na zajedničkom upravljanju članova, a ne samo poduzetništva primarno orijentiranog na profit (Göler von Ravensburg, 2017:10). Interes za otvaranje učeničkih zadruga ili prenamjeni postojećih školskih poduzeća u učeničke zadruge u Njemačkoj je toliko porastao tijekom zadnjeg desetljeća, da kontinuirano postoji lista čekanja za odobrenje u zadružnim savezima (Göler von Ravensburg, 2017:10). U Poljskoj je također zabilježen rast interesa za učeničke zadruge zadnjih godina, i on je vezan uz koncept socijalne ekonomije, koja se vidi kao ključan čimbenik za rast zapošljavanja, socijalne kohezije i društvenog kapitala. U nacionalni program razvoja socijalne ekonomije iz 2014. uvršteno je i promicanje učeničkih zadruga, po kojemu bi do 2020. bilo poželjno da barem $10 \%$ škola u Poljskoj ima učeničku zadrugu (Brzozowska-Wabik, 2015, prema Zimnoch, 2018:254). U Norveškoj i Finskoj učeničke zadruge, zajedno s drugim oblicima školskih poduzeća, dio su programa obrazovanja za poduzetništvo (Odegard, 2007; Hytinkoski, 2012). Ovaj koncept promovira poduzetničku kulturu i inovativnost te se zalaže za uporabu obrazovnih metoda koje čvršće povezuju teoriju i praksu nasuprot klasičnom školskom

1 Promoviranje koncepta obrazovanja za poduzetništvo unutar Europske unije počinje sa 1986. i eksperimentalnim programom Europske komisije „Obrazovanje za poduzeće“, a s Lisabonskom strategijom (akcijskom planom Europske unije iz 2000.) postaje sve važnija tema. Obrazovanje za održivi razvoj značajnije počinje promovirati organizacija Ujedinjenih naroda s akcijskim planom „Agenda 21“ iz 1992., na koji se nastavlja Strategija za obrazovanje za održivi razvoj, usvojena 2005. te i rezolucija o Desetljeću obrazovanja za održivi razvoj 2005.-2014. 
pristupu i potiče razvoj praktičnih poslovnih vještina kroz simulaciju ekonomskih aktivnosti (Europska komisija, 2005). Unutar ovog koncepta, veća se pažnja počinje davati mini ili školskim poduzećima pa onda i učeničkim zadrugama kao posebnom obliku takvih poduzeća čija je specifičnost solidarnost, briga za opće dobro uz geslo da „plaća više nije jedina motivacija za rad“" (prema Liebel, 2009:193).

Učeničke zadruge oponašaju „prave“ zadruge čime pružaju učenicima praktično iskustvo funkcioniranja takvog oblika gospodarskog udruživanja. Dio su obrazovnog sustava, tj. odgojno-obrazovnih ustanova koje ih osnivaju te su organizirane kao kvazi-zadruge tj. imitiraju pravu zadrugu, no nisu zasebni pravni entiteti. U učeničkim se zadrugama učenici upoznaju i prolaze kroz cijeli proizvodni proces u kojem stvaraju proizvod za tržište te za njega ostvaruju i ekonomsku vrijednost. Uz to prolaze kroz sve dijelove poslovnog procesa „neposredno sudjelujući u pripremi, organizaciji i izvedbi programa (od ideje do plasmana proizvoda), vrednovanju rada te raspodjeli eventualne dobiti, primjereno dobi i zrelosti“ (Posavec, 2017:231). Drugim riječima, učenička zadruga oponaša i sve aktivnosti prave zadruge ili poduzeća (Jagodić i Seršić, 2012:195). U mnogim, posebno manjim lokalnim zajednicama, učeničke zadruge igraju važnu komponentu u dinamici suradnje između škole i njezina okruženja - roditelja, drugih škola, poduzeća, organizacija civilnog društva, drugih zadruga i lokalnih vlasti. U nekim zemljama, poput Njemačke, sve su učeničke zadruge od početka čvrsto povezane s pravom zadrugom iz lokalnog okruženja, koja im predstavlja stalnog partnera i mentora (Göler von Ravensburg, 2017:11).

U sklopu učeničkih zadruga učenici se mogu baviti poljoprivredom (u školskim vrtovi$\mathrm{ma}$ ), izradom raznih uporabnih predmeta, ukrasa, rukotvorina te starim zanatima, ali i novim medijima i tehnologijama. Uobičajeno je zadruga organizirana u nekoliko sekcija koje pokrivaju razne sektore - od uzgoja biljaka ili voćki, prerade hrane, cvjećarskih, pčelarskih, preko onih koje se bave preradom otpada i ekologijom, do onih zanatskih koje su usmjerene na izradu tradicionalnih proizvoda i suvenira.

\subsection{Učeničke zadruge i zadružni identitet}

Učeničke su zadruge i konceptualno i povijesno usko povezane $s$ „pravim“ zadrugama i racionalna je pretpostavka da se temelje na zadružnim vrijednostima i načelima, tj. onima koji su danas poznati pod sintagmom „zadružni identitet“. Ovaj okvir za jedinstven pristup zadrugama odredio je 1995. Međunarodni savez zadruga kada je usvojena tzv. Izjava o zadružnom identitetu, koja određuje uporište zadruga u sedam načela i deset vrijednosti. Takva deklaracija o zadružnom identitetu povezana je s potrebom osnaživanja zadrugarstva i jačanjem uloge zadruga u svijetu kojim je dominirao ekonomski model usmjeren na profit i privatne interese. MacPherson navodi kako je ova deklaracija nastala kao reakcija na četiri glavna trenda tog vremena: raspad planskih ekonomija Srednje i Istočne Europe; nejasne uloge zadruga u mnogim zemljama Juga; dominaciju tržišnih ideologija i klasične liberalne misli; i rastuću globalnu integraciju kroz tehnologiju (MacPherson, 2004:40). Zadrugarstvo se u tom kontekstu javlja kao protuteža, jer predstavlja oblik gospodarskog udruživanja koje nema za cilj samo ekonomsku korist (dobit), nego i brigu za svoje članove, za zajednicu i okoliš. U tradiciji je zadrugara poštivanje etičkih vrijednosti poput pošte- 
nja, otvorenosti i prihvaćanja različitih, društvene odgovornosti i brige za druge (Rodgers, 2015:ii) pa su onda i vrijednosti koje čine temelj zadružnog identiteta: uzajamna pomoć, odgovornost, demokracija, ravnopravnost, pravičnost i solidarnost. Prema Izjavi o zadružnom identitetu, zadruga se definira kao samostalna organizacija osoba okupljenih dragovoljno kako bi zadovoljili svoje zajedničke ekonomske, socijalne i kulturne potrebe i želje kroz zajedničko demokratski vođeno poduzeće (Rodgers, 2015:ii).

Iz definicije proizlaze i temeljna zadružna načela, a to su: 1. dragovoljno i otvoreno članstvo (članstvo je u zadruzi dragovoljno i otvoreno za sve osobe koje mogu koristiti njezine proizvode / usluge i koje su spremne prihvatiti odgovornosti članstva, bez ikakve diskriminacije na temelju spolne, rasne, socijalne, političke, vjerske ili bilo koje druge pripadnosti) (Rodgers, 2015:5); 2. demokratsko upravljanje (zadruga je demokratsko udruženje čiji članovi zajedno upravljaju zadrugom sudjelujući u odlukama po načelu ,jedan član, jedan glas") (Rodgers, 2015:15); 3. gospodarsko sudjelovanje članova (članovi ravnopravno, sukladno svojim interesima i mogućnostima, doprinose kapitalu svoje zadruge, čiji je barem jedan dio u zajedničkom vlasništvu, a veći dio viška prihoda raspoređuju u razvoj zadruge) (Rodgers, 2015:29); 4. samostalnost i neovisnosti zadruge (zadruga djeluje neovisno od državnih tijela i druge vanjske aktere te se oslanja na rad svojih članova koji nadziru zadrugu i zadružne resurse) (Rodgers, 2015:45); 5. obrazovanje, stručno usavršavanje i informiranje članova (zadruga kontinuirano pruža obrazovanje svojim članovima i njihovo usavršavanje, kako bi što učinkovitije upravljali svojom zadrugom te informira javnost i mlade o prirodi i prednostima suradnje i zadrugarstva) (Rodgers, 2015:57); 6. suradnja među zadrugama (potiče se suradnja s drugim zadrugama na lokalnoj, nacionalnoj, međunarodnoj razini s ciljem jačanja članova i zadružnog pokreta) (Rodgers, 2015:71); i na koncu 7. briga za zajednicu (zadruga se brine i doprinosi održivom razvoju svoje lokalne zajednice) (Rodgers, 2015:85).

Izjava o zadružnom identitetu kroz zadnja je dva desetljeća ugrađena u politike Europske unije, pristupe međunarodnih organizacija (poput Ujedinjenih naroda (UN), Međunarodne organizacije rada (ILO) i dr.), i prilagodbe nacionalnih zakonodavstava, pa tako i hrvatskog, koje je sa Zakonom o zadrugama iz 2011. (NN, 34/11, 125/13, $76 / 14,114 / 18,98 / 19)$ postalo uskladenije s ovim dokumentom, odnosno europskim i globalnim standardima.

\section{PREGLED ISTRAŽIVANJA O UČENIČKIM ZADRUGAMA}

Istraživanja o učeničkim zadruga još su uvijek nedostatna. $S$ obzirom na veću pozornost koju su učeničke zadruge dobile s politikama i strategijama za održivi razvoj, društveno poduzetništvo ili obrazovanje za poduzetništvo, ne čudi kako su i neka od recentnijih istraživanja usmjerena upravo na te teme.

Jedan od pristupa promatra učeničke zadruge unutar paradigme obrazovanja za poduzetništvo. Vrančić i Lovrenčić (2013) nastoje razumjeti kako se uvodi podučavanje poduzetničkih kompetencija kao međupredmetne teme u odgojno obrazovni sustav. $\mathrm{U}$ studiji slučaja učeničke zadruge koja ima naglašeni cilj učenja za poduzetništvo, ukazuju 
kako zadružni model može pratiti suvremene trendove obrazovanja i novih industrija. Neki su autori ukazali na potrebu za svestranim obrazovanjem voditelja zadruge, koji treba obuhvatiti znanja i vještine iz specifičnog tehničko-tehnološkog područja, poduzetničko-ekonomskog i pedagoškog područja (Tkalec i sur., 2013). U sličnom je smjeru provedeno nekoliko istraživanja koji su se bavili ulogom nastavnika-voditelja zadruga i njihovih vještina. Primjerice, istraživanje koje je provedeno na uzorku od 33 učeničke zadruge Splitsko-dalmatinske županije pokazalo je kako nastavnici-voditelji posjeduju menadžerske vještine te da one nisu uvjetovane starosnom dobi niti spolom (Babić $\mathrm{i}$ Šitum, 2014:55). Neke od studija ističu problem nedovoljnog valoriziranja rada nastavnika i učitelja - voditelja učeničke zadruge. Primjerice, istraživanje o zadovoljstvu radom u učeničkoj zadruzi i poduzetničkim sklonostima voditelja zadruge provedeno je na uzorku od 34 učitelja ili nastavnika koji su voditelji učeničkih zadruga u školama Varaždinske županije (Posavec, 2017). Podaci su pokazali kako je tek 38,2\% ispitanika odabralo taj angažman samovoljno te kako sklonost za poduzetničko ponašanje voditelja nije ključan čimbenik pri formiranju učeničkih zadruga (Posavec, 2017:147). Iako se nisu izravno bavili učeničkim zadrugama svom istraživanju o obrazovanju za poduzetnost u hrvatskim školama, Baranović i suradnici (2007) nastojali su utvrditi kako učitelji i nastavnici percipiraju aktivnosti škole i nastavne metode kojima se potiče razvoj poduzetnosti učenika i kako procjenjuju poduzetničke osobine i ponašanje učenika. Usputni nalaz pokazao je kako od 25 osnovnih škola u uzorku, njih sedam s učeničkim zadrugama imale su iskustvo i koristile nastavne metode kojima se učenike potiče na surađivanje s lokalnom zajednicom i poučava kako vlastitim angažmanom mogu zaraditi novac za vlastite potrebe (Baranović i sur., 2007:351).

Drugi pristup recentnih istraživanja učeničkih zadruga polazi od paradigme održivog razvoja. Tu treba spomenuti studiju u Njemačkoj, koja je pokušala razumjeti povezanost učeničkih zadruga s ciljevima obrazovanja za održivi razvoj (Göler von Ravensburg, 2017). Neki od rezultata ove studije, koja je obuhvatila 50 učeničkih zadruga, kroz tri kruga intervjua i anketa s učenicima i nastavnicima, provedenim od 2006. do 2012., pokazuju kako postoji snažna percepcija kako zadružni model značajno doprinosi razvoju učenika, posebno u srednjim školama. Studija ukazuje na to kako model učeničkih zadruga stavlja učenike u ulogu sukreatora u obrazovnom procesu, gdje im je posebno važna povezanost $s$ pravim zadrugama u lokalnoj zajednici te kako većina nastavnika percipira da učenje koje se događa u učeničkim zadrugama osnažuje opće stavove prema zadrugama i doprinosi razvoju ključnih kompetencija za održivost (Göler von Ravensburg, 2017:34-35). Istraživanje koje se temelji na studiji slučaja studentske zadruge na Sveučilištu Kanzas također je ukazalo kako zadružni model potiče zajedničko djelovanje prema ciljevima od općeg dobra te kako upravo taj model učenja može biti posebno koristan kod podučavanja ,zelenog“" ponašanja i održivog razvoja (Alavosius i Newsome, 2012:83).

$\mathrm{Na}$ koncu, treba spomenuti i pristup koji promatra odgojnu funkciju učeničkih zadruga i nastoji mjeriti promjene nekih aspekata stavova i ponašanja kod učenika-zadrugara. $U$ tom je smislu zanimljivo istraživanje Peko i suradnika koji su proveli eksperiment na 96 
parova učenika osnovnih škola. Parovi izjednačeni po glavnim obilježjima - spolu, dobi i školskom uspjehu, a razlikovali su se jedino po tome jesu li ili nisu članovi učeničke zadruge. Rezultati su pokazali da učenici-zadrugari pokazuju značajniju razinu samopoštovanja od ostalih učenika (Peko i sur., 2005).

\section{UČENIČKE ZADRUGE U HRVATSKOM KONTEKSTU}

Literatura o učeničkim zadrugama u Hrvatskoj još je uvijek oskudna i osim nekolicine novijih istraživačkih radova, dostupno je nešto literature nastale od 50-ih do 80-ih godina. Većina tih radova dolazi iz pedagoških disciplina i bave se raznim aspektima učeničkih zadruga u kontekstu organizacije škole, izvannastavnih aktivnosti te odgojno-obrazovnog procesa.

Po nalazima dostupne literature koje su dale obrise povijesnog tijeka razvoja učeničkog zadrugarstva, učeničke zadruge izvorno nastaju s pokretom nove škole i reformirane pedagogije krajem 19. te početkom 20. stoljeća, vrlo vjerojatno u Francuskoj, odakle su se proširile i dalje po Europi te i šire (Lendić Kasalo i sur. 2008:23). Podaci ukazuju da su prve zadruge osnovane 80-ih godina 19. stoljeća. Među prvim su poznatim učeničkim zadrugama učenička zadruga „Omorika“, osnovana kao dio osnovne škole dr. Josipa Pančića u Bribiru 1881. i „Jabuka“ osnovana 1882. u okviru osnovne škole Milka Trnina iz Križa. Učeničko zadrugarstvo tako slijedi razvoj „pravog zadrugarstva“, jer se kao prve zadruge u Hrvatskoj spominju „Pitomačka zanatnička zadružnica“, osnovana kao obrtnička zadruga u Pitomači 1862. te štedno-kreditna poljoprivredna zadruga osnovana 1864. u Korčuli (Mataga, 2005:21; Hrvatski poljoprivredni zadružni savez, 2020). Početak učeničkih zadruga teško je utvrditi i zbog toga što postoji niz srodnih pojmova koji se javljaju kao preteča učeničkog zadrugarstva, poput nastave gospodarstva i kućanstva, ratarnica, školskih vrtova, malih gospodarstava pri školama, radnih škola, a u referentnoj literaturi se tek 1956. spominje pojam učeničke zadruge (Franković, 1956, prema Lendić Kasalo i sur., 2008:22).

Prve učeničke zadruge u Hrvatskoj organizirane kao štedno- kreditne služile su za nabavku školskog pribora i opreme te za zdravstvene ili humanitarne akcije (Lendić Kasalo i sur., 2008:23). No, veći razvoj učeničkih zadruga počinje oko školskih vrtova, te s njima i počinje njihova veća orijentacija na proizvodnju (Slačanac i Munjiza, 2007:88). Upravo se na proizvodnu funkciju počinju nadovezivati aktivnosti učeničkih zadruga kroz proizvodnju voćnih sadnica ili cjepiva za lozu, koje bi si se onda dijelile lokalnom stanovništvu s ciljem razvoja poljoprivrede i gospodarstva. No, kako neki autori navode, učeničke zadruge u toj prvoj fazi vezanosti za školske vrtove nisu imale tržǐ̌nu orijentaciju, no postojao je sustav nagrađivanja učitelja i učenika koji su sudjelovali u radu i proizvodnji u okviru učeničkih zadruga - i to nagradama u vidu sadnica, sjemenja, košnica i sl. (Lendić Kasalo i sur., 2008:24-25). Do danas su aktivnosti uz školske vrtove i poljoprivredne djelatnosti ostale značajno zastupljene među poslovima učeničkih zadruga. Za prvu polovinu 20. stoljeća, do kraja Drugog svjetskog rata, nema dovoljno izvora o učeničkom zadrugarstvu pomoću kojih bi se mogla rekonstruirati dinamika njihova ra- 
zvoja u tom periodu. U socijalističkom razdoblju hrvatske povijesti dolazi do institucionalnog prepoznavanja učeničkih zadruga, koje dobivaju svoje mjesto u odgojno-obrazovnom sustavu. Reforme školstva tijekom pedesetih i šezdesetih godina 20. stoljeća uvode koncept „slobodnih“ ili ,izvannastavnih“ aktivnosti u školski program, u koje se učenici mogu dobrovoljno uključiti prema svojim interesima. Na učeničke se zadruge u socijalističkom periodu gledalo i kao na „oblik učeničkih radnih brigada kroz različite oblike društveno-korisnog rada" (Lendić Kasalo i sur., 2008:25). U ovom se razdoblju afirmira i proizvodno-tržišna dimenzija, u smislu prihodovanja od proizvodnje i načina raspodjele prihoda iz kojih se najčešće nabavljaju sredstva za rad, knjige, školski pribor ili podmiruju troškovi učeničkih ekskurzija (Franković, 1958, prema Lendić Kasalo i sur., 2008:26).

Literatura ukazuje i na to kako post-socijalističke / komunističke europske zemlje imaju slične puteve zadrugarstva pa onda i učeničkog zadrugarstva. Tijekom socijalističkog i(li) komunističkog režima zadruge su ostale bez svojih temelja - demokratskog upravljanja nad zajedničkom imovinom zadrugara te su instrumentalizirane za potrebe i propagandu vladajuće ideologije (Les i Jeliazkova, 2007). U periodu nakon tranzicije uslijedio je svojevrstan animozitet prema zadrugama, na koje se gledalo kao na relikt socijalizma i prisilne kolektivizacije (Borzaga i Spear, 2004; Vidović, 2012), a što je vodilo gašenju velikog broja zadruga i njihovom sustavnom zanemarivanju. $U$ isto vrijeme događa se i zastoj u razvoju učeničkih zadruga. Iako nema mnogo tragova u postojećoj literaturi, spominje se kako „u promijenjenim društvenim i političkim uvjetima učeničke zadruge nepotrebno dobivaju i političku konotaciju“ te kako „nije bilo daleko od njihove administrativne zabrane" (Lendić Kasalo i sur., 2008:26).

No, sa 1995. i inicijativom Hrvatske zajednice tehničke kulture počinje revitalizacija učeničkog zadrugarstva. Te godine Ministarstvo prosvjete i športa donosi „Program učeničkog zadrugarstva u osnovnim i srednjim školama"2, a iste se godine održava tzv. „obnoviteljska“ smotra učeničkog zadrugarstva koja je okupila 30 učeničkih zadruga (Lendić Kasalo i sur., 2008:26). Od 1997. ove smotre postaju ponovno redovna godišnja manifestacija. Zakon o osnovnom školstvu iz 1990. propisuje za osnovne škole mogućnost osnivanja učeničke zadruge kao oblika izvannastavne aktivnosti učenika te implicira kako je to jedan od modela „društveno korisnog rada učenika“ (NN, 59/90, čl. 31). Isti Zakon određuje kako se proizvodi, nastali kao rezultat rada učeničke zadruge, mogu stavljati u promet, a sredstva ostvarena prometom koja se posebno evidentiraju mogu se koristiti isključivo za rad zadruge. No, prvi zakoni o srednjem školstvu nakon osamostaljenja Hrvatske ne sadrže propise o osnivanju učeničkih zadruga. Tek od 2008., s objedinjavanjem propisa za osnovnoškolsko i srednjoškolsko obrazovanje u Zakonu o odgoju i obrazovanju u osnovnoj i srednjoj školi (NN, 87/08, 86/09, 92/10, 105/10, 90/11, 5/12, 16/12, 86/12, 126/12, 94/13, 152/14, 07/17, 68/18, 98/19, 64/20), ovi propisi, uz vrlo minimalne sadržajne preinake, počinju vrijediti i za sred-

2 Dokument je objavljen u Glasniku Ministarstva prosvjete i športa, broj 12, Zagreb, 14. studenog 1995. 
nje škole. Iz toga je vidljivo kako institucionalno određenje te vrlo oskudna zakonska regulacija učeničkih zadruga utvrđena pedesetih godina 20. stoljeća i dalje čini okvir za njihovo osnivanje i djelovanje. Tim okvirom određeno je kako su učeničke zadruge oblik izvannastavne proizvodne aktivnosti vezan uz obrazovne institucije koje nemaju status samostalnog pravnog oblika. Dozvoljeno im je djelovati na tržištu, uz primjenu neprofitne klauzule tj. uz obvezu reinvestiranja dobiti za potrebe djelovanja zadruge. ${ }^{3}$ Nova etapa u razvoju učeničkog zadrugarstva kreće od 2006., a obilježilo ju je osnivanje Hrvatske udruge učeničkog zadrugarstva (HUUZ). Odluka o osnivanju ove udruge, kao neke vrste nacionalnog potpornog i koordinacijskog tijela pod ingerencijom resornih državnih institucija proistekla je iz procesa tadašnjih reformi školstva. S HUUZom uspostavlja se intermedijarna struktura koja facilitira osnivanje učeničkih zadruga, vodi evidencije, organizira smotre i edukacije za učitelje i nastavnike te posreduje u dogovorima s lokalnim vlastima. $U$ institucionalnom smislu HUUZ umanjuje nedostatke oskudnog zakonskog okvira pa nudi upute kako pokrenuti zadrugu ili kako izraditi pravilnik. S HUUZ-om započela je i službena evidencija, tj. registar učeničkih zadruga pa je moguće pratiti promjene u njihovoj dinamici u zadnjih 13 godina. Od osnutka HUUZ-a broj se učeničkih zadruga sa 120 u 2006. popeo na 602 u 2019. (HUUZ, 2019a) pa je očito zamjetan utjecaj ove udruge na promociji učeničkog zadrugarstva. Kao dio ove institucionalne stabilizacije u razvoju učeničkog zadrugarstva treba spomenuti i uspostavu kolegija Učeničko zadrugarstvo od 2006. na Učiteljskom fakultetu Sveučilišta u Zagrebu.

U hrvatskom obrazovnom sustavu danas gotovo polovica škola (46\%) ima osnovanu učeničku zadrugu. Najveći broj učeničkih zadruga, njih 468 (78\%), djeluje u okviru osnovnih škola, 105 učeničkih zadruga djeluje u okviru srednjih škola, a 29 ih je osnovano u centrima za odgoj i obrazovanje. $\mathrm{Na}$ srednjoškolskoj razini obrazovanja gotovo sve učeničke zadruge javljaju se u strukovnim školama i umjetničkim školama, koje i imaju za cilj pripremiti učenike za uključivanje na tržište rada. Regionalno, sjeverna i istočna Hrvatska imaju snažniju tradiciju zadrugarstva, pa su među županijama s izrazito visokim udjelom učeničkih zadruga (dvije trećine škola imaju učeničku zadrugu) Sisačko-moslavačka, Karlovačka, Varaždinska, Koprivničko-križevačka i Bjelovarsko-bilogorska županija. Na samom su dnu Dubrovačko-neretvanska i Istarska županija, gdje svaka četvrta ili peta škola ima osnovanu učeničku zadrugu.

Prema dostupnim izvorima o povijesti učeničkog zadrugarstva u Hrvatskoj vidljivo je kako su obrazovna i odgojna funkcija uvijek bile u temelju učeničkih zadruga. Neki drugi aspekti postupno su evoluirali - od volonterskog rada, humanitarne pomoći, pre-

3 Zakon o odgoju i obrazovanju u osnovnoj i srednjoj školi (NN, 87/08, 86/09, 92/10, 105/10,90/11, $5 / 12,16 / 12,86 / 12,126 / 12,94 / 13,152 / 14,07 / 17,68 / 18,98 / 19,64 / 20)$ definira osnivanje učeničkih zadruga u u tri stavka Članka 39: 1. Škola može osnovati učeničku zadrugu kao oblik izvannastavne aktivnosti sukladno statutu škole i posebnim propisima; 2. Škola može stavljati u promet proizvode nastale kao rezultat rada učenika; 3. Sredstva stečena prometom proizvoda i usluga učeničke zadruge posebno se evidentiraju, a mogu se upotrijebiti samo za rad učeničke zadruge i unapređenje odgojno-obrazovnog rada. 
ko proizvodnih djelatnosti, te većeg naglaska na kolektivnoj prirodi i društvenoj brizi, do afirmiranja tržišne funkcije. No, literatura ne tematizira sve aspekte zadružnog identiteta u djelovanju učeničkih zadruga. Na primjer, gotovo se uopće ne dotiče upravljačke dimenzije pa ostaje nejasno jesu li i na koji način učenici-zadrugari bili uključeni u procese donošenja odluka u vezi s proizvodnjom, aktivnostima, poslovanjem učeničkih zadruga i reinvestiranjem te raspodjelom prihoda te na koji se način taj aspekt mijenjao kroz vrijeme.

Za bolje shvaćanje učeničkih zadruga i njihove uloge u obrazovanju za zadrugarstvo, jedan je od glavnih ciljeva rada pokušati razumjeti na koji način učeničke zadruge u svom djelovanju reflektiraju zadružna načela. Na koji su način zadružna načela primjenjiva na učeničke zadruge? U kojoj su mjeri po tome slične „pravim“ zadrugama? Mogu li se učeničke zadruge razumjeti kao poligoni učenja o zadrugarstvu i inkubatori budućih zadrugara? Neki su od ciljeva ovog rada pokušati ponuditi odgovore na ova pitanja. No, prije svega, smatramo važnim i ovim radom doprinijeti većoj vidljivosti učeničkih zadruga koje su zapostavljene kao predmet akademskih istraživanja te postaviti temelje za daljnja istraživanja u ovom smjeru.

\section{METODOLOGIJA}

Rad se temelji na eksplorativnom pristupu i kvalitativnoj metodologiji. Sastoji se od desk-metoda deskriptivne analize sekundarnih podataka dostupnih u bazi učeničkih zadruga koju vodi Hrvatska udruga učeničkih zadruga. Primarni podaci prikupljeni su metodama fokus grupe i polu-strukturiranog intervjua. Fokus grupe su održane $s$ učenicima-članovima učeničkih zadruga, dok su u intervjuima sudjelovali nastavnici-voditelji učeničkih zadruga, kao i predstavnici HUUZ-a kao glavne potporne organizacije unutar institucionalnog okvira. Glavne teme diskusija u fokus grupama uključivale su: 1. opća pitanja vezana uz motivaciju za sudjelovanje u zadruzi, opis glavnih aktivnosti i vremena koje provode u aktivnostima zadruge; 2 . participaciju i uključenost u procese odlučivanja; 3 . suradnju, inkluzivnost i solidarnost unutar zadruge; 4. proizvodnju i poduzetništvo; 5. povezanost s lokalnom zajednicom i odnos prema okolišu; 6. poteškoće $s$ kojima se susreću u djelovanju zadruge i načini rješavanja poteškoća; 7. percepciju vrijednosti koje vežu uz zadrugu. Glavne teme polustrukturiranog intervjue s voditeljima učeničkih zadruga vezane su uz: 1. procese upravljanja aktivnostima u zadruzi; 2. procese odlučivanja u zadruzi i način uključivanja učenika; 3 . proizvodnja i poduzetništvo u zadrugama; 4. najvažnije kompetencije koje učenici stječu u zadrugama; 5. povezanost s lokalnom zajednicom i odnos prema okolišu; 6 . poteškoće s kojima se susreću u djelovanju zadruge i načini rješavanja poteškoća; 7. percepciju vrijednosti koje vežu uz učeničku zadrugu.

Za odabir učeničkih zadruga korištena je strategija namjernog uzorkovanja. Odabrano je deset učeničkih zadruga iz različitih dijelova Hrvatske - pet iz osnovnih škola te pet iz srednjih škola. Kako bi se osigurala veća heterogenost uzorku, po dvije učeničke zadruge (jedna koja djeluje unutar osnovne škole i druga koja djeluje unutar srednje ško- 
le) odabrane su iz pet široko obuhvaćenih geografskih regija istočna (Slavonija), južna (Dalmacija), Istra, središnja i primorska te sjeverna (uključujući Zagreb). Provedeno je deset fokus grupa, u kojima je sudjelovalo 58 učenika-zadrugara. Fokus grupe trajale su od 32 minute do 1 sat 18 minuta (u prosjeku 53 minute). Uz fokus grupe, provedeno je 11 intervjua - deset $s$ voditeljima učeničkih zadruga (istih u kojima su provedene fokus grupe) i jedan s predstavnikom HUUZ-a. Intervjui su trajali od 14 minuta do 43 minuta (u prosjeku 32 minute). Terenski dio istraživanja proveden je od listopada 2018. do siječnja 2019. godine. Svi intervjui i fokus grupe održane su u prostorijama škola ili prostorima HUUZ-a. ${ }^{4}$

Nakon što su voditelji učeničkih zadruga ili ravnatelji škola pristali na zatraženo sudjelovanje u istraživanju, sudionici istraživanja bili su unaprijed informirani o njegovoj svrsi. Za sudjelovanje učenika u fokus grupama roditelji su unaprijed trebali potpisati informirani pristanak. Svi razgovori snimani su uređajem za audio snimanje te su potom transkribirani. Podaci su analizirani tematskom analizom uz primjenu deduktivnog pristupa (Braun i Clarke, 2006:83-84). Sedam zadružnih načela, definiranih u Izjavi o zadružnom identitetu činilo je okvir unaprijed zadanih tema u analitičkom instrumentu, prema kojima su podaci iz fokus grupa i intervjua kodirani pa povezani prema srodnim kategorijama / temama.

Istraživanje je provedeno u skladu s etičkim kodeksom struke i načelom povjerljivosti. Iskazi sudionika anonimizirani su te se u prikazima izvornih iskaza ne koriste informacije koje bi mogle identificirati sudionike (u tom smislu pojmovi koji mogu identificirati kazivača zamijenjeni su neutralnim pojmovima). U iskazima se koriste oznake oš $V x$ ili $s{ }^{r} V \mathrm{x}$ za iskaze voditelja učeničkih zadruga te ošUČx ili sšUČx za iskaze učenika zadrugara, gdje oznake oš ili sš označavaju osnovnu ili srednju školu, a broj nakon V ili UČ numeraciju učeničke zadruge u uzorku. Jedan od najvećih izazova u istraživanju bio je razgovor $s$ djecom i mladima tinejdžerske dobi, što je iziskivalo od istraživača poseban pristup, koji je uključivao jezičnu prilagodbu i pojednostavljenje složenih koncepata, kao i manje formalnu komunikaciju.

Valjanost i pouzdanost istraživanja povećane su kroz tehnike triangulacije; korištene su različite metode prikupljanja podataka (fokus-grupe, polu-strukturirani intervjui) $s$ različitim akterima unutar populacije učeničkih zadruga (učenici-zadrugari, voditelji) te uz sudjelovanje dvaju istraživača u istraživačkom timu. Po pitanju poopćavanja u kvalitativnim istraživanjima oslanjamo se na analitičku i naturalističku generalizaciju. Analitička generalizacija uključuje „obrazloženo rasuđivanje“ o tome u kojem se opsegu rezultati jedne studije mogu uzeti kao vodič za ono što se može očekivati u drugoj studiji, dok naturalistička generalizacija počiva na osobnom iskustvu koje se kreće od prešutnog znanja o tome što jest do očekivanja i ekplicitno pretpostavljenog znanja (Kvale, 1996:232-233).

4 Dio podataka korišten je za izradu tematskog izvještaja „Učeničke zadruge: model učenja o participaciji i (društvenom) poduzetništvu unutar odgojno-obrazovnog sustava" u sklopu Obrazovne zviždaljke GOOD Inicijative i u suradnji s Institutom za društvena istraživanja Zagreb (vidjeti Vidović i Grubišić-Čabo, 2019). 


\section{REZULTATI I DISKUSIJA}

U ovom su poglavlju prikazani i organizirani rezultati prema tematskom okviru koji je služio za analizu kvalitativnih podataka dobivenih kroz fokus grupe i intervjue. Tablica 1 prikazuje sažet pregled glavnih kategorija prema svakoj temi, odnosno zadružnom načelu. U nastavku će se dati detaljniji rezultati i diskusija za svaku temu / zadružno načelo.

Tablica 1. Sažet pregled glavnih kategorija kodiranja iz rezultata fokus grupa i intervjua

\begin{tabular}{|l|l|}
\hline \multicolumn{1}{|c|}{ Teme / zadružna načela } & \multicolumn{1}{c|}{ Kategorije } \\
\hline Dragovoljno i otvoreno članstvo & $\begin{array}{l}\text { Otvoreno na poziv nastavnika } \\
\text { Otvoreno za „bolje“ učenike } \\
\text { Nejasno kako se ulazi u zadrugu } \\
\text { Nedragovoljno sudjelovanje } \\
\text { Prihvaćanje različitosti }\end{array}$ \\
\hline Demokratsko upravljanje članova & $\begin{array}{l}\text { Neformalno i sporadično sudjelovanje u odlukama } \\
\text { Izostanak sudjelovanja } \\
\text { Osnaživanje samopouzdanja kroz sudjelovanje }\end{array}$ \\
\hline Gospodarsko sudjelovanje članova i & $\begin{array}{l}\text { Razvoj poduzetničkih vještina } \\
\text { Integracija učenika } \\
\text { Suradnja } \\
\text { Raspodjela }\end{array}$ \\
\hline Samostalnost i neovisnost zadruge & $\begin{array}{l}\text { Atmosfera i vrijednost izvannastavne aktivnosti } \\
\text { Isprepletenost s praktičnom nastavom }\end{array}$ \\
\hline $\begin{array}{l}\text { Obrazovanje, stručno usavršavanje i } \\
\text { informiranje članova zadruge }\end{array}$ & $\begin{array}{l}\text { Nedovoljna osposobljenost voditelja } \\
\text { HUUZ kao potpora }\end{array}$ \\
\hline Suradnja među zadrugama & Smotre \\
\hline Briga za zajednicu & $\begin{array}{l}\text { Prepoznavanje socijalnih i drugih problema } \\
\text { Briga o okolišu }\end{array}$ \\
\hline
\end{tabular}

\subsection{Dragovoljno i otvoreno clanstvo}

Ovo načelo odražava primarno pravo ljudi na slobodno udruživanje s drugima, kako bi ostvarivali zajedničke ciljeve (Rodgers, 2015:5-14). Ono prethodi drugim načelima, jer je u temelju zadružne kulture nužnost slobodnog izbora te svako prisilno uključivanje u zadruge protivi se ovom temeljnom načelu. Načelo također promiče i uključivost i toleranciju prema različitima, posebice prema osjetljivijim ili obespravljenim skupinama društva. Slobodan odabir učlanjenja u zadrugu sa sobom nosi i odgovornost prema drugim članovima i zajedničkim ciljevima i imovini.

Dokumenti o učeničkim zadrugama ukazuju na primjenu ovog načela. Učeničke zadruge određuju se kao oblik izvannastavnih aktivnosti učenika koji dragovoljno pristupaju zadruzi prema svojim interesima. HUUZ navodi kako „dragovoljnim učlanjenjem u 
zadrugu učenik preuzima obvezu rada u njoj na najbolji mogući način. Tako postaje suodgovoran za njen rad i uspjeh ili neuspjeh..." (Bučar, 2011).

Učeničke zadruge smatraju se otvorenima svim učenicima u školi te im oni mogu pristupiti i postati članovi sekcija koje odgovaraju njihovim interesima. Dragovoljno sudjelovanje odnosi se i na učitelje i nastavnike koji se uključuju u rad zadruge kao njezini voditelji ili kao voditelji pojedinih sekcija.

Tablica 2. Sažetak rezultata za temu dragovoljno i otvoreno članstvo

\begin{tabular}{|c|c|c|}
\hline $\begin{array}{c}\text { Tema / } \\
\text { zadružno načelo }\end{array}$ & Kategorija & Primjeri \\
\hline \multirow{5}{*}{$\begin{array}{l}\text { Dragovoljno } \\
\text { i otvoreno } \\
\text { članstvo }\end{array}$} & $\begin{array}{l}\text { Otvoreno na } \\
\text { poziv nastavnika }\end{array}$ & $\begin{array}{l}\text { sšUČ15: Da, mogu (postati članovi zadruge op.a.). U } \\
\text { početku, profesorica pita tko se želi uključiti i onda se } \\
\text { javljaju. } \\
\text { I: Znači dobrovoljna je i ne postoji nikakva prisila, ili ne? } \\
\text { sšUČ (11-16, svi): Da }\end{array}$ \\
\hline & $\begin{array}{l}\text { Otvoreno za } \\
\text { „bolje“ učenike }\end{array}$ & $\begin{array}{l}\text { sšUČ55: Prvenstveno biraju profesori one koji malo bolje } \\
\text { rade. Koji se trude. } \\
\text { š̌UČ49: Ja mislim da profesori kad vide da se mi } \\
\text { zalažemo i da radimo od prve da je nekako profesori } \\
\text { steknu povjerenja u nas i vide s kojim učenicima mogu } \\
\text { koliko i šta raditi. }\end{array}$ \\
\hline & $\begin{array}{l}\text { Nejasno kako se } \\
\text { ulazi u zadrugu }\end{array}$ & $\begin{array}{l}\text { ošUČ1: Mi vam prvih mjesec dana, pola godine nismo } \\
\text { uopće znale da mi idemo u zadrugu. To je bilo više } \\
\text { ono, kad bi nas nastavnica pozvala, dodite pomoći ovo, } \\
\text { napravite ovo i tako. }\end{array}$ \\
\hline & $\begin{array}{l}\text { Nedragovoljno } \\
\text { sudjelovanje }\end{array}$ & $\begin{array}{l}\text { I: Kako to da ste vi odlučili preuzeti, ako smijem pitati? } \\
\text { ošV1: Nisam odlučila. (...) To je bilo zaduženje koje sam } \\
\text { dobila. } \\
\text { I: Od ravnatelja? } \\
\text { ošV1: Da. } \\
\text { I: A kako to da niste odbili? Nitko od vas? } \\
\text { sšUČ52: Zato što to ulazi u ocjenu. U zalaganje i sve. }\end{array}$ \\
\hline & $\begin{array}{l}\text { Prihvaćanje } \\
\text { različitosti }\end{array}$ & $\begin{array}{l}\text { ošUČ2: Pa, ovo može zvučati djetinjasto, zato što svi tako } \\
\text { kažu...ali ja isto mislim da učimo poštovati jedni druge i } \\
\text { raditi zajedno. }\end{array}$ \\
\hline
\end{tabular}

Rezultati istraživanja pokazuju kako ovo načelo nije uvijek jednoznačno primijenjeno i kako postoje različite interpretacije dragovoljnog članstva. Primjena ovog načela kreće se od otvorenog za sve, preko dostupnog samo za neke, uglavnom za bolje učenike ili one koji se trude, do toga da neki osjećaju obvezu ili prinudu sudjelovanja u učeničkoj zadruzi. Za neke sudionike nije jasno ni kako se učlanjuje u zadrugu, jer su ih nastavnici jednostavno pozvali da povremeno nešto pomognu ili odrade. Učenici se nekad osjećaju 
„uključeni“" u zadrugu bez svoje volje, i doživljavaju je kao dio nastavnog procesa te stoga i obveznu, jer to ulazi u ocjenu i $u$ zalaganje. Česti se kroz iskaze prepoznaje kako učenici nisu adekvatno informirani o tome što je učenička zadruga, niti da se radi o izvannastavnoj dragovoljnoj aktivnosti, a često se redovne aktivnosti nastave isprepliću $s$ aktivnostima zadruge. Nedragovoljnost sudjelovanja odnosi se i na nastavnike, koji nisu uvijek slobodnom voljom odabrali voditi zadrugu, već im je to zaduženje dodijelio ravnatelj. U nekim su slučajevima učitelji i nastavnici „prisiljeni“ postati voditelji učeničkih zadruga, zbog nedovoljne norme ostvarene u redovnoj nastavi, iako za to nisu imali posebnu sklonost niti interes.

Važan je uvid poticanje otvorenosti i prihvaćanje različitosti kod učenika, što neki od sudionika dovode u vezu sa sudjelovanjem u zadruzi. Suradnja s drugima kroz procese u zadružnom djelovanju omogućuju učenicima iskustva upoznavanja drugih ljudi, upoznavanja tudeg načina razmišljanja te razvijanja poštovanja prema drugima.

\subsection{Demokratsko upravljanje članova}

Načelo demokratičnosti podrazumijeva mogućnost članova zadruga da upravljaju i kontroliraju djelovanje organizacije kroz sudjelovanje u procesima odlučivanja. No, koliko god bilo kompleksno provesti ovo načelo u praksi rada zadruga, inzistiranje na njemu znači „osnaživati duh demokracije unutar zadruga“, što je „društveno vrijedan i supstancijalan zadatak" (Rodgers, 2015:15). U tome se i vidi jedna od ključnih uloga zadruga; one se vide kao rasadnici demokratskog korijenja u društvu (Rodgers, 2015:15).

Kako u praksi izgleda postupak osnivanja te upravljanje učeničkom zadrugom u Hrvatskoj? Kada se pojavi interes, škola pokreće osnivanje učeničke zadruge. Nakon nastavničkog vijeća, prijedlog ide na školski odbor, koji, ukoliko se složi, o tome informira Ministarstvo znanosti i obrazovanja, jedinicu lokalne samouprave i HUUZ te otvara posebni račun za poslovanje zadruge. Nakon toga, upravitelj/ica saziva osnivačku skupštinu, koja usvaja statut, pravilnik i program rada zadruge te nominira nekog od nastavnika za upravitelja učeničke zadruge. Skupština bira predsjednika, tajnika te razna tijela učeničke zadruge. Zadružni odbor kao upravno tijelo zadruge čini (uglavnom) 7 članova koje imenuje / bira Školski odbor, i to 2 iz redova osoblja škole, 1 iz reda roditelja učenika članova, 1 iz reda suosnivača odnosno članova Zadruge, 2 iz reda učenika zadrugara, 1 člana predstavnika jedinice lokalne samouprave.

Demokratsko je tijelo zadruge skupština, a čine je učenici zadrugari, učitelji i nastavnici koji su voditelji zadruge ili voditelji sekcija, zainteresirani roditelji koji žele doprinijeti radu zadruge, vanjski suradnici, predstavnici lokalne uprave i samouprave i drugi zainteresirani građani ili počasni članovi. Osim u glasanju na skupštini, participacija učenika-zadrugara i drugih uključenih u rad zadruge može se ostvariti i u drugim aspektima. Primjerice, prijedlog godišnjeg plana i programa rada zadruge ili sekcije izrađuje voditelj, i takav prijedlog služi kao polazni nacrt dokumenta oko kojeg se „vodi razgovor $s$ učenicima, roditeljima i ostalim sudionicima koji na bilo koji način učestvuju u radu sekcije“" (Bučar i sur., 2008:39). 
Tablica 3. Sažetak rezultata za temu demokratsko upravljanje članova

\begin{tabular}{|c|c|c|}
\hline $\begin{array}{c}\text { Tema / } \\
\text { zadružno načelo }\end{array}$ & Kategorija & Primjeri \\
\hline \multirow{3}{*}{$\begin{array}{l}\text { Demokratsko } \\
\text { upravljanje } \\
\text { članova }\end{array}$} & $\begin{array}{l}\text { Neformalno } \\
\text { i sporadično } \\
\text { sudjelovanje u } \\
\text { odlukama }\end{array}$ & $\begin{array}{l}\text { ošV3:Pa recimo, zajednički donosimo cijenu proizvoda, } \\
\text { zajednički osmišljavamo izgled proizvoda, zajednički } \\
\text { dolazimo do ideja śta će se uopće raditi. Pa čak i kod } \\
\text { kreiranja godišnjeg plana i programa uzmemo nekakve } \\
\text { dogadaje, kad ćemo imati te prodajne izložbe u školi } \\
\text { pa onda već tu dogovaramo šta bi se moglo i od kojih } \\
\text { materijala. } \\
\text { sšUČ39: Pa da, dosta nas se pita (...) uglavnom, što god } \\
\text { da mi kažemo, i ako ima imalo smisla to se realizira, } \\
\text { prihvati se naš prijedlog } \\
\text { š̌V8: Uvažavamo njihovo mišljenje, znači njihovi } \\
\text { prijedlozi su uvijek dobrodošli. }\end{array}$ \\
\hline & $\begin{array}{l}\text { Izostanak } \\
\text { sudjelovanja }\end{array}$ & $\begin{array}{l}\text { I: Dobro, a kako se odlučuje što ćete raditi? Je li vi vi } \\
\text { nekako sudjelujete u odlučivanju? } \\
\text { sšUČ (48-56, svi): Ne. } \\
\text { I: A što mislite, zašto ne sudjelujete? } \\
\text { sšUČ 53: Pa zato što imamo dobre profesore. Mislim } \\
\text { imamo profesoricu koja je stvarno kreativna i buba ideje, } \\
\text { ali mi kao... mislim, ja iskreno ne bih stavila učenike da } \\
\text { daju ideje, jer to bi bilo onda malo previše toga svega. }\end{array}$ \\
\hline & $\begin{array}{l}\text { Osnaživanje } \\
\text { samopouzdanja } \\
\text { kroz sudjelovanje }\end{array}$ & $\begin{array}{l}\text { ošUČ2: Meni se svida to, kad smo u zadruzi, k’o da } \\
\text { sam na istoj razini s nastavnicima, mi najnormalnije } \\
\text { pričamo s njima, k’o da smo odrasli ljudi i tako bez } \\
\text { veze čavrljamo i možemo raditi što volimo, kreativno se } \\
\text { izražavati, prodavati i glumiti prodavače. } \\
\text { ošUČl: Svida mi se što je ta neka razina odgovornosti } \\
\text { koja je na nas oslonjena i da nastavnici viruju u nas, da } \\
\text { smo mi dovoljno ozbiljni da to nešto radimo. }\end{array}$ \\
\hline
\end{tabular}

Rezultati su pokazali kako u zadrugama uključenim u istraživanje postoje različite prakse participacije učenika-zadrugara. U nekim zadrugama učenici percipiraju kako su dovoljno uključeni u odluke oko zadruge, dok u drugima smatraju kako ih se malo pita. Uobičajeno razumijevanje sudjelovanja u odlučivanju ograničeno je na davanje i prihvaćanje prijedloga oko procesa proizvodnje i prodaje u zadruzi. No, rezultati ukazuju kako se uobičajeno radi o neformalnim i sporadičnim procesima odlučivanja koji ne uključuju niti formalna tijela (nitko od sudionika nije spomenuo skupštinu) niti formalne procedure.

Ostvarivati uspješno demokratsko upravljanje u učeničkim zadrugama čini se vrlo kompleksnim zadatkom. Tome je tako, jer samo postavljanje načela demokratičnosti kao važećeg ne znači i poznavanje njegove primjene. U društvu u kojem se demokratska 
kultura postupno i dugotrajno usvaja, teško je očekivati da su učitelji i nastavnici vješti u uspostavljanju i osiguravanju demokratskih procesa. Takvo se stanje reflektira i na populaciju mladih. Recentna istraživanja utvrdila su kako je među mladima prisutan značajan demokratski deficit, s obzirom na njihove političke vrijednosti i participaciju (Gvozdanović, i sur., 2019). Pokazalo se kako „većina mladih podržava demokraciju kao dobar oblik vladavine, ali istodobno u znatnoj mjeri prihvaćaju i autoritarni način vladanja“, a takvo „selektivno prihvaćanje liberalno-demokratskih vrijednosti upućuje na nedostatno razumijevanje demokratskih načela i pravila" (Gvozdanović i sur., 2019:43). Rezultati ukazuju na važnost participacije u procesima upravljanja zadrugom, koju učenici prepoznaju kroz prihvaćenost i poštivanje, kao da su na istoj razini s nastavnicima $\mathrm{i}$ da nastavnici vjeruju u njih, da su dovoljno ozbiljni. Istraživanja su pokazala kako participativni procesi osnažuju učenike u procesu odrastanja, i mogu utjecati na njihovo veće samopoštovanje (Peko i sur., 2005).

\subsection{Gospodarsko sudjelovanje članova i raspodjela}

Svrha je zadruga prvenstveno zadovoljiti potrebe ljudi i zajednice, stvoriti samoodrživost, a ne akumulirati kapital. Ovo načelo ukazuje na načine kako članovi zadruge posluju i stvaraju prihode i dobit te kako ih raspoređuju. U objašnjenju ovog načela napominje se kako je „cijela struktura zadruge kreirana oko koncepta kapitala koji je u službi ljudi i rada, a ne rada i ljudi koji služe kapitalu“" (Rodgers, 2015:30).

Gospodarska aktivnost inherentna je u djelovanju učeničkih zadruga, jer se one osnivaju s proizvodno-gospodarstvenim ciljevima. Kako učenička zadruga svoje proizvode i usluge prodaje na tržištu tako ima ,sve funkcije gospodarskog subjekta, poput nabave, proizvodnje, prodaje" (Bobanac i Tratnik, 2008:85). S osnivanjem definiraju se područja proizvodnje oko kojih postoji interes ili resursi (poput poljoprivrednog zemljišta ili školskog vrta), kao i proizvodi koji će se nuditi na tržištu. Unutar jedne zadruge najčešće postoje barem dvije ili tri sekcije, a neke učeničke zadruge imaju ih desetak i više. Učenička zadruga može ostvarivati financijske prihode, a njezino poslovanje i imovina vode se na posebnom računu škole te njega vodi školska računovodstvena služba i ta se sredstva mogu koristiti samo za aktivnosti i potrebe zadruge.

Rezultati istraživanja ukazuju kako učenici općenito sudjeluju u različitim procesima proizvodnje i poslovanja što percipiraju važnim aspektom sudjelovanja u zadruzi. Imitirajući „pravu“ zadrugu kao gospodarsko udruženje, učeničke zadruge percipiraju se kao mjesta gdje učenici mogu iskusiti praksu te razviti poduzetničke vještine i srodne sposobnosti za svijet rada, poduzetnistva. U iskazima se spominje i izgradnja samostalnosti, koja učenicima daje samouvjerenost da poslije mogu sami raditi. U iskazima se ističe učenje odgovornosti kroz rad zadrugu, jer postaneš jednostavno svjestan da nešto jednostavno moraš, ne možeš sad to odgoditi za prekosutra ili stjecanje samostalnosti, koja učenicima daje samouvjerenost da poslije mogu sami raditi.

Gospodarske se aktivnosti unutar zadruge prepoznaje kao posebno važan model za (radnu) integraciju lošijih učenika ili učenika s poteškoćama u razvoju. 
Tablica 4. Sažetak rezultata za temu gospodarsko sudjelovanje članova i raspodjela

\begin{tabular}{|c|c|c|}
\hline $\begin{array}{c}\text { Tema / } \\
\text { zadružno načelo }\end{array}$ & Kategorija & Primjeri \\
\hline \multirow{4}{*}{$\begin{array}{l}\text { Gospodarsko } \\
\text { sudjelovanje } \\
\text { članova i } \\
\text { raspodjela }\end{array}$} & $\begin{array}{l}\text { Razvoj } \\
\text { poduzetničkih } \\
\text { vještina }\end{array}$ & $\begin{array}{l}\text { sšV8: Kad je zadruga krenula nije bio cilj da se učenici } \\
\text { vode kao učenici nego da oni stvarno nešto konkretno } \\
\text { rade da nauče da izadu osposobljeni za taj neki svet rada, } \\
\text { poduzetništva, to nam je bio cilj na početku. } \\
\text { sšUČ49: Pa, ako nemaš pristup kupcu (...), moraš imati te } \\
\text { neke društvene sposobnosti i u zadruzi ih još više razvijaš, } \\
\text { mislim ako ne znaš kako pristupiti kupcu, ako ne znaš } \\
\text { kako predstaviti proizvod i kako ga zainteresirati, zapravo } \\
\text { taj proizvod nećeš prodati, mislim proizvod se neće prodati } \\
\text { sam od sebe, tako da ono to je jedan plus koji ti može } \\
\text { pomoći iz zadruge za budućnost. } \\
\text { sšUČ40: Pa ja bi možda rekla i samostalnost zato što mi } \\
\text { naučimo te stvari mi možemo poslije sami raditi znači } \\
\text { nama ne treba nitko, mi sad to znamo I nama ne treba } \\
\text { nitko, mi možemo sami raditi. }\end{array}$ \\
\hline & $\begin{array}{l}\text { Integracija } \\
\text { učenika }\end{array}$ & $\begin{array}{l}\text { ošV11: Mi smo uključivali takvu djecu koja su imala } \\
\text { probleme između ostalog jer nisu možda mogli naći svoje } \\
\text { mjesto u razredu (...) Oni onda zapravo, u razredu su } \\
\text { bili: aha, ja sam u zadruzi, ako se priča o nečemu onda } \\
\text { su mogli i oni pričati o tome što su oni radili I tako dalje. } \\
\text { Tako da su zapravo bili uključeniji i samim time su oni } \\
\text { bili zadovoljniji (...) tu se vidjela promjena. }\end{array}$ \\
\hline & Suradnja & $\begin{array}{l}\text { ošUČ11: Kad netko nešto zna, pomažemo jedni drugima } i \\
\text { tako riješimo sve probleme. } \\
\text { sšUČ39: Ako netko i ne zna onda sve naučiti polako uz } \\
\text { nas svih i svi zajedno pomognu (buka) i onda osoba svlada } \\
\text { i može raditi samostalno poslije. }\end{array}$ \\
\hline & $\begin{array}{l}\text { Raspoređivanje } \\
\text { dobiti }\end{array}$ & $\begin{array}{l}\text { ošUČ5: I sad kad mi zaradimo od prodaje te novce, } \\
\text { ponovno trošimo na materijal s kojim ćemo raditi. Tako da } \\
\text { uvik su dobro potrošeni. } \\
\text { ošUČ28: Mislim da bi bilo korisno uložiti novac u kupnju } \\
\text { knjiga za djecu, jer možda neke obitelji imaju manje } \\
\text { novaca i ne mogu si priuštiti kupovinu svih knjiga, jer to } \\
\text { može biti jako skupo. } \\
\text { ošV6: Recimo jedne godine to je baš bila ideja učenika, su } \\
\text { se vi ovi ormarići oni lokeri tako zvani po školama kupili } \\
\text { od tih novaca. }\end{array}$ \\
\hline
\end{tabular}

Suradnjom i timskim radom kroz koju se odvija proizvodnja u zadrugama takvi su učenici bili višse uključeni $i$ zadovoljniji, što ukazuje kako se kroz zadružne aktivnosti događa 
i integracija u radne procese i društvo, što je posebno važno za socijalno osjetljive ili isključene skupine. Važan su dio odnosa unutar gospodarskih aktivnosti zadruge timski rad i pomaganje ( $k a d$ netko nešto zna, pomažemo jedni drugima), što je važno za učenje o temeljnoj vrijednosti zadrugarstva kao ekonomskog modela kojeg predstavlja suradnja, nasuprot rivalstvu i kompeticiji.

U ekonomskom smislu, za zadrugu je nužno ostvarivati višak ili dobit, jer to znači da uspijeva osigurati održivost i vitalnost organizacije. Prema ovom načelu, višak se u zadruzi može upotrijebiti za razne svrhe, poput razvoja i unapređenja zadružnog poslovanja, ulaganja u modernizaciju ili ljudske resurse, u edukaciju i treninga članova, zaposlenika ili opće populacije, razvoja novih djelatnosti, za neki oblik nagrađivanja članova zadruge te za potporu socijalnih ili kulturnih aktivnosti (Rodgers, 2015:40-41).

$\mathrm{Na}$ koje sve načine učeničke zadruge raspoređuju dobit? Uobičajeno je ulaganje u kupovinu materijala i opreme koja je potrebna za rad pojedinih sekcija, poput sirovina (drvo, vuna, vosak, glina), opreme i kućanskih aparata za kuhinju i radionice domaćinstva, ili sadnica i košnica za školski vrt. Nekad se za rad u zadruzi učenici nagrađuju besplatnom školskom prehranom, posjetama izložbama, izletima ili sajmovima ( $p a$, kad biramo učenike koji će putovati u pravilu biramo i te učenike koji su iz zadruge, neka im to bude neka vrsta nagrade (sšV8)). Spominju se i donacije za potrebe učenika slabijeg imovinskog statusa, ali i socijalno osjetljivim skupinama građana ili udrugama. Samo u jednoj zadruzi iz uzorka, u kojoj je zapaženo najviše elemenata imitacije prave zadruge, učenici su za svoj rad u zadruzi dobivali nagrade u vidu kvazi-plaća. U drugom slučaju zadruge, u kojoj su se mogli identificirati niske razine dragovoljnosti i participacije, nesudjelovanje u raspodjeli dobiti doprinosi negativnoj percepciji (mi stvarno radimo (...) i ne dobijemo nikakav poticaj). I nastavnici angažirani kao voditelji zadruga iskazuju nezadovoljstvo kompenzacijama za taj angažman. Niska norma od 2 sata za vođenje zadruge nerijetko je razlog odlaska voditelja iz zadruge, što nekad dovodi u pitanje i opstanak zadruge.

\subsection{Samostalnost $i$ neovisnost zadruge}

Ovo je načelo uvedeno $s$ namjerom reguliranja odnosa zadruga s nacionalnim vladama, drugim organizacijama i poduzećima. U tom smislu, zadruga nije samostalna niti nezavisna ukoliko je ne kontroliraju njezini članovi, i to u skladu s otvorenom, transparentnom i odgovornom demokratskom praksom (Rodgers, 2015:46).

Učenička zadruga djeluje kao izvannastavna aktivnost u okviru škole te nema status samostalnog pravnog subjekta. Isto tako, ne može imati vlastiti žig niti vlastiti račun ni računovodstvo niti joj pripadaju ikakva prava koja bi imala kao nezavisno gospodarsko udruženje. Zadruga je usko vezana uz školu koja je osniva, poput „interesne skupine“ (Grđan i Zbanatski, 2008:34-35). Škola kao osnivač daje učeničkoj zadruzi slobodu samostalnog djelovanja, no to može biti uvjetovano općim planom i programom škole. Rezultati ukazuju na to da učenici imaju pozitivna iskustva u slučajevima kada je zadruga organizirana kao izvannastavna aktivnost; osjećaju se opuštenije i bolje povezani $s$ nastavnicima ili imaju dojam kako uče više u stvarnom procesu rada. No, u nekim 
zadrugama, aktivnosti zadruge nisu eksplicitno odvojene od redovne praktične nastave, već se s njom isprepliću, što može utjecati na manju povezanost sa zadrugom i smanjen identitet zadrugara. Vremenska i prostorna odvojenost aktivnosti učeničke zadruge od procesa redovne nastave zasigurno kompenzira nedostatak formalne neovisnosti učeničke zadruge kao zasebne organizacije.

Tablica 5. Sažetak rezultata za temu gospodarsko sudjelovanje članova i raspodjela

\begin{tabular}{|c|c|c|}
\hline $\begin{array}{c}\text { Tema / } \\
\text { zadružno načelo }\end{array}$ & Kategorija & Primjeri \\
\hline \multirow{2}{*}{$\begin{array}{l}\text { Samostalnost } \\
\text { i neovisnost } \\
\text { zadruge }\end{array}$} & $\begin{array}{l}\text { Atmosfera } \\
\text { i vrijednost } \\
\text { izvannastavnih } \\
\text { aktivnosti }\end{array}$ & $\begin{array}{l}\text { ošUČG: Ja smatram da mi ovdje možemo pričati dosta } \\
\text { opuštenije s razrednicom i s drugim nastavnicima. (...) } \\
\text { Nikada nije dosadno u isto vrijeme i radimo, tako se i } \\
\text { zabavljamo, prođe nam brže vrime. } \\
\text { sšUČ39: (...) šta nismo na nastavi, jer mi zapravo tek } \\
\text { tada učimo, jer nas ne može nijedan udžbenik naučiti } \\
\text { kako mi trebamo s ljudima razgovarati kako se mi prema } \\
\text { njima trebamo postaviti. Mi zapravo učimo kada nismo na } \\
\text { nastavi kad smo na tim sajmovima. }\end{array}$ \\
\hline & $\begin{array}{l}\text { Isprepletenost } \\
\text { s praktičnom } \\
\text { nastavom }\end{array}$ & $\begin{array}{l}\text { sšUČ53: Mi smo u razredu i mi u sklopu razreda, znači } \\
\text { našeg 3. razreda, radimo s profesorom. Znači, profesor } \\
\text { nadgleda, s tim da kad smo se već ispraksirali, već znamo } \\
\text { tko zna, što treba. } \\
\text { sšUČ48: Nije to tako! Mi imamo program, znači, recimo } \\
\text { sad radimo u svom programu određeni predmet, radimo } \\
\text { vježbu. I kad se to završi, ako ima nešto za zadrugu što, ne } \\
\text { znam, onda ovi koji završe podjele posao. }\end{array}$ \\
\hline
\end{tabular}

\subsection{Obrazovanje, stručno usavršavanje i informiranje članova zadruge}

Obrazovanje je jedno od fundamentalnih načela zadružnog pokreta. Još na samim počecima društvene okolnosti bile su takve da je obrazovanje bilo privilegija rijetkih, a istodobno ključno za transformaciju društvenog položaja (Rodgers, 2015:57). Stoga su rane zadruge nastojale učiniti obrazovanje dostupnim ne samo svojim članovima, nego i široj zajednici, a posebno mladima. Smatra se kako su upravo obrazovni napori zadruga najviše utjecali na širenje ideja i razvoj zadružnog pokreta.

Ovo načelo se odnosi na razumijevanje i primjenu zadružnih načela u poslovanju zadruge; razvoj praktičnih vještina za učinkovito, etično i demokratsko upravljanje zadrugom te podučavanje opće javnosti i posebno mladih o zadrugama, vrijednostima i načelima zadrugarstva, i dobrobiti koju zadruge donese društvu (Rodgers, 2015:59). Načelo je imanentno učeničkoj zadruzi, jer se radi o mjestu kontinuirane poduke i praktičnog učenja. HUUZ ima važnu ulogu u primjeni ovog načela, posebice u edukaciji nastavnika-voditelja učeničkih zadruga (HUUZ, 2015:3). 
Tablica 6. Sažetak rezultata za temu obrazovanje, stručno usavršavanje i informiranje članova zadruge

\begin{tabular}{|c|c|c|}
\hline $\begin{array}{c}\text { Tema / } \\
\text { zadružno načelo }\end{array}$ & Kategorija & Primjeri \\
\hline \multirow[t]{2}{*}{$\begin{array}{l}\text { Obrazovanje, } \\
\text { stručno } \\
\text { usavršavanje i } \\
\text { informiranje } \\
\text { članova zadruge }\end{array}$} & $\begin{array}{l}\text { Nedovoljna } \\
\text { osposobljenost } \\
\text { voditelja }\end{array}$ & $\begin{array}{l}\text { ošV7: Ali malo je meni to previše na moja leda jer } \\
\text { ja trebam materijale nabaviti, raditi sa djecom, } \\
\text { držat ih, motivirati, cijelo vrijeme biti s njima, } \\
\text { voditi brigu o koliko su oni umorni, da li su pojeli, } \\
\text { da li ćemo čaj napraviti, jel', pa onda treba pisati } \\
\text { papire, kurikulum, pratiti, fotografirati, zapisivati, } \\
\text { finiširati, unos-iznos s novcem, mislim, nema kraja } \\
\text { to stvarno k’o da imaš svoj mali biznis i sad jedna } \\
\text { osoba da ga radi. } \\
\text { ošV11: Onaj administrativni dio koji morate pokriti } \\
\text { sa skupštinama, izborima, statutima... to je ono } \\
\text { nešto s čim se zapravo... Mislim, mi nismo pravnici, } \\
\text { ne bi smjeli biti administratori. I onda je to nama } \\
\text { (...) zapravo nešto što je drukčije, novo, relativno } \\
\text { nepoznato, to prvi puta napraviti je zapravo bilo } \\
\text { jako teško. }\end{array}$ \\
\hline & HUUZ kao potpora & $\begin{array}{l}\text { ošV11: Ona je najviše pomogla jer je ona dugo, dugo } \\
\text { vremena u Hrvatskoj zajednici zadruga. Pa je ona } \\
\text { onda, ja sam nju nazvao, zamolio za pomoć, i onda } \\
\text { sam ja često odlazio kod nje, ona mi je pokazivala } \\
\text { točno što, kako, gdje, davala nekakve savjete i tako } \\
\text { dalje. Ona je stvarno, stvarno bila ta koja je taj dio } \\
\text { mi puno pomogla odraditi. }\end{array}$ \\
\hline
\end{tabular}

Ono što se u rezultatima pokazalo kao česta tema osjećaj je nedovoljne osposobljenosti nastavnika za ulogu voditelja zadruge. To se prvenstveno odnosi na administriranje svih procesa (nešto drugačije za nas iz prosvjete, novo, nepoznato), ali i preopterećenost velikim brojem obveza koje uloga nosi (sve vam je to se strmi nekome na leda). Iz iskaza se prepoznaje kako neki nalaze pomoć i potporu u HUUZ-u, koji se i u praksi pojavljuje kao glavni akter u promoviranju i educiranju o učeničkom zadrugarstvu.

Posebna se komponenta ovog načela tiče informiranja o zadrugarima i dobrobitima zadrugarstva. Ova dimenzija posebno utječe na drugo načelo, tj. demokratičnost zadruge (Rodgers, 2015:61), jer obrazovanje omogućuje zadrugarima da razumiju i preuzmu odgovornost u demokratskom upravljanju. Rezultati ovog istraživanja implicitno ukazuju i na to da svi sudionici nedovoljno poznaju zadružna načela i zadrugarstvo. Slabo poznavanje značenja zadrugarstva identificirano je i na razini zadružnog sektora, gdje se „needuciranost članova zadruga i zadružnoga menadžmenta o zadružnom načinu poslovanja" vidi kao jedno od naslijeđenih i postojećih strukturnih slabosti zadrugarstva (Pejnović i sur., 2017:59). 


\subsection{Suradnja medu zadrugama}

Ovo načelo predstavlja praktični izraz vrijednosti solidarnosti i po tome se zadruge razlikuju od drugih gospodarskih udruženja i društava kapitala (Rodgers, 2015:71). Kroz suradnju i trgovinu s drugim zadrugama, zadruge doprinose jačanju zadružnog sektora. Kao intermedijarna nacionalna organizacija učeničkog zadrugarstva HUUZ ima značajnu ulogu u ostvarivanju ovog načela. Jedna od aktivnosti ove udruge poticanje je „razvoja, suradnje i umrežavanja učeničkih zadruga te razvitak međužupanijske suradnje u učeničkom zadrugarstvu", ali i organiziranje smotre učeničkog zadrugarstva na županijskoj, međužupanijskoj i državnoj razini (HUUZ, 2015:3). Dio aktivnosti koje provodi HUUZ je i međunarodna suradnja s učeničkim zadrugama u inozemstvu. Iz godišnjih izvješća HUUZ-a vidljivo je kako se uglavnom radi o bilateralnim suradnjama sa susjednim zemljama, poput Srbije, Bosne i Hercegovine, Crne Gore, Makedonije i Slovenije, s kojima Hrvatska dijeli dio zajedničke povijesti učeničkog zadrugarstva.

Tablica 7. Sažetak rezultata za temu suradnja među zadrugama

\begin{tabular}{|c|c|c|}
\hline $\begin{array}{c}\text { Tema / } \\
\text { zadružno načelo }\end{array}$ & Kategorija & Primjeri \\
\hline $\begin{array}{l}\text { Suradnja među } \\
\text { zadrugama }\end{array}$ & Smotre & $\begin{array}{l}\text { sšUČ49: Meni je poznanstva, znači prijateljstva i } \\
\text { širenje međusobnog znanja, tipa na tim smotrama, } \\
\text { netko će mene nečemu podučiti, ja ću nekoga } \\
\text { podučiti znači, a tré́a stvar timski rad, kako sve se } \\
\text { zajednički napravi. } \\
\text { ošV7: To su škole, one čudesna rade, od proizvoda, } \\
\text { paleta, svašta od uporabnih, nosivih, odječe, } \\
\text { opreme, igračaka, drva, pića, nema šta nema, k’o } \\
\text { jedan sajam, znate kako sajam u Zagrebu izgleda, } \\
\text { Velesajam, tako smo mi jedan mali Velesajam s } \\
\text { proizvodima koje djeca rade. } \\
\text { ošV6: Ne znam što bih još dodala, možda to } \\
\text { nekakvo druženje to je jako lijepo, steknu tu i } \\
\text { prijateljstva kroz te smotre (...) mislim da ja je to } \\
\text { jako važno, danas kad su svi na kompjuteru. }\end{array}$ \\
\hline
\end{tabular}

Važan su dio učeničkog zadrugarstva smotre, koje se organiziraju jednom godišnje, a na kojima se predstavljaju proizvodi učeničkih zadruga. U rezultatima su upravo smotre učeničkog zadrugarstva prepoznate kao mjesta koja imaju veliku (može se reći i jedinu) ulogu u povezivanju s drugim zadrugama. Na smotrama, koje se svake godine održavaju u drugom gradu, učenici se predstavljaju, natječu, osvajaju nagrade, ali i povezuju s drugima na način suradnje i razmjene znanja (netko će mene nečemu podučiti, ja ću nekoga podučiti znači, a treća stvar timski rad, kako sve se zajednički napravi). 


\subsection{Briga za zajednicu}

Ovo načelo proizlazi iz same naravi zadruga; one nastaju u lokalnim zajednicama u koje su duboko ukorijenjene i s kojima su čvrsto povezane svojim djelovanjem. Način na koji djeluju zadruge doprinosi održivom razvoju lokalnih zajednica što podrazumijeva brigu za tri aspekta: ekonomskom, socijalnom i ekološkom. Još od samih početaka zadrugarstva, neki ciljevi prvih zadruga bili su usmjereni na poboljšanje života zadrugara te osnaživanje zajednice kroz pružanje obrazovanja, kroz socijalne i kulturne aktivnosti (Rodgers, 2015:85).

Povezanost zadruga sa zajednicom više je od poslovne; zadruge su otvorene drugim članovima u zajednici, a posebno su solidarne i spremne pomoći onima u lošijem položaju. U kontekstu diskursa o ekološkim problemima i održivom razvoju, školski vrtovi (ponovo) dobivaju važnu ulogu kao prostor edukacije i razvoja odgovornosti prema okolišu, ali i kao izvor sirovina u izradi prirodnih prehrambenih i ljekovitih proizvoda (vidi Falamić i Feldi Drašinac, 2017).

Tablica 8. Sažetak rezultata za temu briga za zajednicu

\begin{tabular}{|c|c|c|}
\hline $\begin{array}{c}\text { Tema / } \\
\text { zadružno načelo }\end{array}$ & Kategorija & Primjeri \\
\hline & $\begin{array}{l}\text { Prepoznavanje } \\
\text { socijalnih i } \\
\text { drugih problema }\end{array}$ & $\begin{array}{l}\text { ošV3: Čak od djece smo znali dobivati poticaje za } \\
\text { nekakve humanitarne aktivnosti. Jer djeca se mectusobno } \\
\text { bolje poznaju, znaju gdje je potreba. Nedavno smo imali } \\
\text { jednu akciju za jednog učenika nižih razreda. Dijete ima } \\
\text { leukemiju i mogu vam reći da smo skupili preko } 2000 \\
\text { kuna. } \\
\text { sšUČ43: Pa mislim, ne znam sad točno, ne znam je li } \\
\text { ovo dobar primjer, ali tipa, ajmo reći viška proizvoda } \\
\text { koje znamo da se neće prodati odnesemo u Crveni križ, } \\
\text { Caritas. }\end{array}$ \\
\hline $\begin{array}{l}\text { Briga za } \\
\text { zajednicu }\end{array}$ & Briga o okolišu & $\begin{array}{l}\text { ošV11: Naša zadruga se bazirala na ekološkoj } \\
\text { proizvodnji, poljoprivrednoj, sad da li je to bilo povrće ili } \\
\text { voće ovisno, ovisno koje godine. } \\
\text { ošUČ 4: Na primjer sapuni naši ili labela i sve što je } \\
\text { tako, mi to sve nam je prirodno, nema nikakvih loših } \\
\text { kemikalija. A sad kao firme koriste puno kemikalija za } \\
\text { hranu i za svakakve produkte. A i za robu i za svašta što } \\
\text { mi koristimo mi recikliramo staru robu i svašta stavimo } \\
\text { što imamo da se ne baci. I tako, recikliramo sve. } \\
\text { š̌UČ } 16: \text { Pa na primjer, bili smo dali prijedlog da se } \\
\text { tamo očisti park, da možemo biti vani na marendi kad je } \\
\text { odmor, i onda smo se nešto dogovarali da ćemo to očistiti, } \\
\text { ili ne znam, kažemo da nam stavi neke klupice pa i jesu. }\end{array}$ \\
\hline
\end{tabular}


Implicitni uvidi istraživanja ukazuju kako povezanost $s$ akterima iz lokalne zajednice u kojoj djeluje učenička zadruga u velikoj mjeri ovisi o angažmanu voditelja zadruge ili ravnatelja škole. Veličina se zajednice također čini relevantnim čimbenikom pa je u manjim zajednicama učenička zadruga prepoznata kao važan akter i u aktivnostima zadruga uobičajeno sudjeluju mnogi članovi zajednice, poput roditelja, lokalnih poduzetnika te predstavnika lokalne samouprave

Rezultati ukazuju kako je sudjelovanje u učeničkim zadrugama povezano sa solidarnošću među učenicima, ali i prema široj zajednici. Učenici zadrugari samostalno uspijevaju prepoznati probleme i potrebe u zajednici (djeca se medusobno bolje poznaju, znaju gdje je potreba) te razvijaju socijalnu osjetljivost, empatiju i brigu za one u lošijem položaju. U tom se smislu uobičajeno organiziraju humanitarne akcije za prikupljanje novca ili druge pomoći za druge učenike ili osobe iz okruženja koje su u nepovoljnom položaju. Kao druga važna kategorija identificirana uz ovu temu briga je za okoliš. Pokazalo se kako se učeničke zadruge mogu bazirati na ekološkoj proizvodnji (voće, povrće, ulje), ili imati ekološke sekcije (sapuni, recikliranje, ekološko vrtlarstvo, ekološki nakit, mirisne vréíce). Iskazi učenika ukazuju na to da im je važna priroda i briga o okolišu, nekad čak i razlog pristupanja u zadrugu (Ja sam se priključio zato što ne želim da planet postane od plastike (ošUČ́19)).

\section{ZAKLJUČCI}

Učeničke zadruge specifičan su oblik odgojno-obrazovnog procesa; više su od modela radno-proizvodne slobodne nastave. Tu se događa suradnja, participacija, solidarnost kroz niz aktivnosti koje nisu nužno niti proizvodne niti tržišne, već temeljene na humanim vrijednostima i brizi za zajednicu i okoliš. Kao dio odgojno-obrazovnog procesa učeničke su zadruge formalizirane i institucionalizirane tijekom pedesetih godina prošlog stoljeća. Dakle, kao takve, predstavljaju jedan od rijetkih (institucionalnih) kontinuiteta prethodnog društvenog i političkog poretka. Za razliku od zadruga, učeničke su zadruge na neki način ostale netaknute post-socijalističkim animozitetom i negativnom percepcijom. Stoga je njihova pozicija danas znatno bolja, i mogu biti model za razvoj poduzetništva i društvenog poduzetništva, model za učenje o održivom razvoju, ali i inkubator za revitalizaciju „pravih“ zadruga. Način na koji su zakonski određene, koji je gotovo nepromijenjen zadnjih više od šezdeset godina, ostavlja dosta prostora za netransparentnost, što ne doprinosi temeljnim vrijednostima i načelima zadrugarstva. Uz to, ukazuje i na to da današnje društvo ne drži previše do zadruga i zadružne ekonomije, pa ne doprinosi stvaranju sustavnog institucionalnog pristupa i podrške, a time utječe na slabiju vidljivost učeničkog zadrugarstva u široj javnosti. Posebno je slaba točka gotovo nikakva institucionalna povezanost zadružnog sektora s učeničkim zadrugama. Tu svakako uzor može biti Njemačka, gdje se školskim zadrugama pri osnivanju dodjeljuje „prava“ zadruga kao partner koji ih kontinuirano mentorira i podučava (Göler von Ravensburg, 2017:11). U tematskoj analizi koju smo primijenili na podatke prikupljene intervjuima i fokus grupama, pokazalo se kako se zadružna načela tek djelomično reflek- 
tiraju u radu učeničkih zadruga. Niti dokumenti koji su relevantni za učeničke zadruge, poput „Pravila učeničke zadruge“ koju nudi HUUZ, ne navode taksativno zadružna načela i vrijednosti. Neka od njih su istaknuta eksplicitno, poput načela dragovoljnog sudjelovanja, dok se neka implicitno podrazumijevaju, poput toga da su zadruge prostori obrazovanja učenika. No, neka fundamentalna načela, prvenstveno demokratsko upravljanje i odgovornost članova ovi dokumenti ne razrađuju na dovoljno precizan način, a niti se primjenjuju u praksi. To je posebno znakovit nedostatak kada se uzme u obzir demokratski deficit kod mladih u Hrvatskoj i njihovo općenito nedovoljno razumijevanje demokratskih načela i procesa (Gvozdanović i sur., 2019).

$\mathrm{Na}$ koncu, ovi nedostaci imaju negativne posljedice na poznavanje i integriranje zadružne kulture i zadružnog identiteta kod učenika zadrugara, što može voditi i nedovoljno velikom interesu za zadružno djelovanje i pokretanje zadruga u odrasloj dobi, pa se teško može tvrditi kako su učeničke zadruge rasadnici zadrugarstva. Iz podataka o dinamici razvoja zadružnog sektora u Hrvatskoj vidimo da on ne raste istom dinamikom kao sektor učeničkih zadruga, štoviše, brojčani pokazatelji ukazuju na priličnu stagnaciju broja zadruga i zadrugara 5 . Dakle, jasno je kako potencijal koji imaju učeničke zadruge nije dovoljno apsorbiran u razvoju zadrugarstva, a dio razloga za takvu diskrepanciju leži i u nedovoljnom utemeljenju učeničkih zadruga u zadružnim načelima i praksi koja iz njih proizlazi.

Jedno od glavnih ograničenja ovog istraživanja proizlazi iz malog uzorka s obzirom na ukupnu populaciju učeničkih zadruga te ne možemo tvrditi da je došlo do zasićenja podacima. No, ovaj je metodološki pristup uspio dohvatiti dinamiku sudjelovanja i dublja značenja, posebno iz perspektive učenika-zadrugara te ukazati na pozitivne refleksije nekih od zadružnih načela u praksi, kao i na glavne probleme i nedostatke. $\mathrm{U}$ tom smislu rezultati studije daju odgovore na postavljena istraživačka pitanja, ali i otvaraju nova područja. Oni mogu biti korisno polazište za sveobuhvatno istraživanje na probabilističkom uzorku ukupne populacije učeničkih zadruga iz cijele Hrvatske uz kombiniranu kvantitativnu i kvalitativnu metodologiju. Daljnja bi istraživanja trebalo usmjeriti prema identificiranju učinaka sudjelovanja u učeničkoj zadruzi na kasnije profesionalne preferencije, kao i dati dublje uvide u modele primjene zadružnih načela u primjerima dobre prakse učeničkih zadruga.

\footnotetext{
5 Nakon promjene zakona 2011., broj zadruga se kretao od 1.033 zadruge u 2012. do 1.218 zadruge u 2016. (Hrvatski centar za zadružno poduzetništvo, 2017). U Hrvatskoj samo pet od 1.000 građana su članovi zadruge, što je iznimno malo u usporedbi s prosjekom EU, gdje je svaki četvrti građanin učlanjen u zadrugu (Švaljek i sur., 2018:49).
} 


\section{LITERATURA}

Alavosius, M. P. i Newsome, W. D. (2012). Cooperatives, Green Behavior, and Environmental Protection. Revista Latinoamericana de Psicología, 44(1): 77-85.

Babić, I. i Šitum, S. (2014). Menadžerska znanja voditelja učeničkih zadruga. Putokazi, 1: $47-56$.

Baranović, B., Štibrić, M. i Domović, V. (2007). Obrazovanje za poduzetnost - perspektiva osnovnoškolskih učitelja i nastavnika. Sociologija i prostor, 45(3-4): 339-360.

Bobanac, M. i Tratnik, M. (2008). Gospodarske osnove učeničkog zadrugarstva. U: Bučar, M. (ur.), Školska učenička zadruga u razvoju djece i mladeži: Priručnik za nastavnike osnovnih i srednjih škola (str. 78-125). Zagreb: Hrvatska udruga učeničkog zadrugarstva.

Borzaga C. i Spear R. (ur.) (2004). Trends and challenges for co-operatives and social enterprises in developed and transition countries. Trento: Edizioni 31.

Braun, V., Clarke, V. (2006). Using thematic analysis in psychology. Qualitative Research in Psychology. 3(2): 77-101.

Bučar (2011). Učeničke zadruge - vježbalište poduzetništva. Hrvatska udruga učeničkog zadrugarstva, rujan 2011. URL: http://www.huuz.hr/Ucenicke-zadruge-S7857 (12.11.2019.)

Bučar, M., Levanić, M., Luić, A. i Štajcer, Đ. (2008). Kurikulum učeničke zadruge. U: Bučar, M. (ur.), Školska učenička zadruga u razvoju djece i mladeži: Priručnik za nastavnike osnovnih $i$ srednjih škola (str. 37-62). Zagreb: Hrvatska udruga učeničkog zadrugarstva.

Europska komisija (2005). Mini Companies in Secondary Education: Final Report of the Expert Group. Bruxelles: Europska komisija. URL: https://ec.europa.eu/ growth/content/mini- companies-final-report-expert-group-0_mt (14.11.2020.)

Falamić, J. i Feldi Drašinac, I. (2017). Učenička zadruga kao nositelj održivog razvoja - Primjer dobre prakse, U: Radek, I. (ur.), Znanstveno-stručni skup Održivi razvoj i odgojno- obrazovni sustav Hrvatske: zbornik radova (str. 425-431). Zadar: Sveučilište u Zadru i Dječji vrtić „Radost“.

Göler von Ravensburg, N. (2017). Pupils' cooperatives and the acquisition of competences for sustainable development. CIRIEC Working Paper, No. 2017/01. URL: http://www.ciriec.uliege.be/wp-content/uploads/2017/02/WP2017-01.pdf (21.05.2020.)

Grđan, J., Zbanatski, B. (2008). Osnivanje i ustroj učeničke zadruge. U: Bučar, M. (ur.), Školska učenička zadruga u razvoju djece i mladeži: Priručnik za nastavnike osnovnih $i$ srednjih škola (str. 31-36). Zagreb: Hrvatska udruga učeničkog zadrugarstva.

Gvozdanović, A., Ilišin, V., Adamović, M., Potočnik, D., Baketa, N. i Kovačić, M. (2019). Istraživanje mladih u Hrvatskoj 2018./2019. Zagreb: Friedrich-Ebert-Stiftung.

Hrvatski centar za zadružno poduzetništvo (2017). Godišnje izvješće o stanju zadružnog poduzetništva za 2016. Zagreb: Hrvatski centar za zadružno poduzetništvo. 
URL: http://digured.srce.hr/arhiva/1697/163385/zadruge.coop/upload_data/site_ files/godisnje- izvjesce-o-stanju-zadruznog-poduzetnistva-2016.pdf (12.11.2019.) Hrvatski poljoprivredni zadružni savez (2020). Povijest zadrugarstva u Hrvatskoj. URL: http://www.hzs.hr/o_zadruzi.htm (14.06.2020.)

Hrvatska udruga učeničkog zadrugarstva (HUUZ) (2015). Statut Hrvatske udruge učeničkog zadrugarstva. URL: http://www.huuz.hr/doc/2784-Statut-HUUZ-a.pdf (12.11.2019.)

Hrvatska udruga učeničkog zadrugarstva (HUUZ) (2019a). O nama. URL: http:// www.huuz.hr/O- nama-S7994 (10.11.2019.)

Hrvatska udruga učeničkog zadrugarstva (HUUZ) (2019b). Pravila učeničke zadruge. URL: http://www.huuz.hr/doc/4411-Pravila-UZ.docx (12.11.2019.)

Hytinkoski, P. A. (2012). Student cooperatives in the light of entrepreneurship education. Universitatea Cooperatist-Comercială din Moldova: Anale ştiințifice, 11: 295- 304.

Jagodić, L. i Seršić, N. (2012). Učenička zadruga kao model poduzetništva. Učenje za poduzetništvo, 2(1): 193-200.

Keats, M. D. (1950). Cooperative education in the Secondary school. Ann Arbor, MI: Proquest.

Kvale, S. (1996). InterViews. An Introduction to Qualitative Research Interviewing. Thousand Oaks, CA: SAGE Publications.

Lendić Kasalo, V., Marković, V. i Munjiza, E. (2008). Učenička zadruga: sastavnica hrvatske škole. U: Bučar, M. (ur.), Školska učenička zadruga u razvoju djece i mladeži: Priručnik za nastavnike osnovnih i srednjih škola (str. 17-30). Zagreb: Hrvatska udruga učeničkog zadrugarstva.

Les, E. i Jeliazkova, M. (2007). The Social Economy in Central East and South East Europe. U: Noya, A. i Clarence, E. (ur.), The Social Economy. Building Inclusive Economies (str. 189-210). Paris: OECD.

Liebel, M. (2009). School pupils' firms and mini-companies in Germany. International Journal of Sociology and Social Policy, 29(3/4): 186-196.

MacPherson, I. (2004). Remembering the Big Picture: the co-operative movement and contemporary communities. U: Borzaga, C. i Spear, R. (ur.), Trends and challenges for co- operatives and social enterprises in developed and transition countries (str. 3949). Trento: Edizioni 31.

Mansell, W. (2011). Co-operative schools: the antidote to academies. The Guardian, 15. kolovoza 2011. URL: https://www.theguardian.com/education/2011/aug/15/ cooperative-schools- antidote-academies-independent (20.06.2020.)

Mataga, Ž. (2005). Poljoprivredno zadrugarstvo u Hrvatskoj: razvoj i temeljni problemi. Sociologija i prostor: časopis za istraživanje prostornoga i sociokulturnog razvo$j a, 43(1): 17-42$.

Meyering, H. R. (1948). Cooperatives: Serious Projects in Most Turkish Schools. The Clearing House: A Journal of Educational Strategies, Issues and Ideas, 23(4): 235-236.

Odegard, K. R. (2007). Entrepreneurship in Education in Norway? U: Remmele, B., Schmette, M. i Seeber, G. (ur.), Educating Entrepreneurship. Didactical Approaches and European Perspectives (str. 13-38). Wiesbaden: Deutscher Universitatsverlag. 
Pejnović, D., Radeljak Kaufmann, P. i Lukić, A. (2017). Utjecaj zadrugarstva na regionalni i ruralni razvoj Hrvatske. Hrvatski geografski glasnik, 79(2): 51-85.

Peko, A., Munjiza, E. i Cindrić, M. (2005). Uloga učeničke zadruge u razvijanju samopoštovanja. U: Matijević, M. (ur.), Zbornik učiteljske akademije u Zagrebu (str. 49-62). Zagreb: Učiteljska akademija u Zagrebu.

Posavec, M. (2017). Zadovoljstvo poslom i poduzetničke sklonosti voditelja učeničkih zadruga. Život i škola: časopis za teoriju i praksu odgoja i obrazovanja, 62(1): 139149.

Rodgers, D. (ur.) (2015). Smjernice o zadružnim načelima. Bruxelles: Međunarodni savez zadruga. URL: https://www.ica.coop/sites/default/files/publication-files/2017-02-15-hrguidance- notefinal-581762885.pdf (23.10.2019.)

Slačanac, I. i Munjiza, E. (2007). Programski sadržaji razredne nastave i mogućnosti njihove realizacije u školskim vrtovima. Život i škola, 17(1): 87-100.

Švaljek, S., Broz, T. i Niemann, B. (2018). Prijedlozi za unapređenje zadružnog gospodarstva u Republici Hrvatskoj. Zagreb: Ekonomski institut.

Tkalec, Z., Quien, M. i Posavec, Z. (2013). Mogućnosti integracije učeničkih zadruga i socijalnog poduzetništva u obrazovnom procesu. Učenje za poduzetništvo, 3(2): 54-61.

Vidović, D. (2012). Socijalno poduzetništvo u Hrvatskoj. Doktorska disertacija. Zagreb: Filozofski fakultet Sveučilište u Zagrebu.

Vidović, D. i Grubišić-Čabo, M. (2019). Učeničke zadruge: model učenja o participaciji i (društvenom) poduzetništvu unutar odgojno-obrazovnog sustava. Tematski izvještaji - Obrazovna zviždaljka. Zagreb: GOOD Inicijativa. URL: http://oz.goo. $\mathrm{hr} / \mathrm{wp}$ - content/uploads/2019/08/OZ_ucenicke_zadruge.pdf (21.11.2019.)

Vrančić, M. i Lovrenčić, S. (2013). Inovacije u radu učeničkih zadruga: Primjer dobre prakse. Učenje za poduzetništvo, 3(2): 46-53.

Zakon o odgoju i obrazovanju u osnovnoj i srednjoj školi. Narodne novine, 87/08, $86 / 09,92 / 10,105 / 10,90 / 11,5 / 12,16 / 12,86 / 12,126 / 12,94 / 13,152 / 14,07 / 17$, $68 / 18,98 / 19,64 / 20$.

Zakon o osnovnom školstvu. Narodne novine, 59/90.

Zakon o zadrugama. Narodne novine, 34/11, 125/13, 76/14, 114/18, 98/19.

Zimnoch, K. (2018). The Role of Student Cooperatives in Education in Poland in the 21st Century. Proceedings of the International Scientific Conference "Rural Environment. Education. Personality (REEP)", No. 11. Jelgava, Latvija, 11.-12. svibnja 2018. URL: https://llufb.llu.lv/conference/REEP/2018/Latvia_REEP_2018_proceedings_ISSN225580 8X.pdf (12.07.2020.) 


\title{
STUDENT COOPERATIVES AS COOPERATIVES' NURSERIES? REFLECTIONS ON COOPERATIVE PRINCIPLES OF STUDENT COOPERATIVES IN CROATIA
}

\author{
Davorka Vidović
}

\begin{abstract}
Student cooperatives are a phenomenon with a long tradition in Croatia and have been formally regulated since 1950s as a form of extracurricular activity within the educational system. In the last 15 years, the number of student cooperatives has increased significantly and there are 602 student cooperatives today, which means that almost half of the schools have established one. This paper presents the results from a survey on student cooperatives in Croatia, which was conducted in 2018 and 2019. The research was based on an exploratory approach and qualitative methodology and used interviews and focus groups on a convenient sample of ten student cooperatives. The paper relies on the International Co-operative Alliance (ICA) as its main conceptual framework, which defines the "cooperative identity" through its seven basic principles and ten values. The purpose of this paper was to determine how these basic cooperative principles are applied in the activities of student cooperatives and whether we can view student cooperatives as a kind of cooperatives' nurseries. The findings revealed that some principles, such as education about cooperatives and democratic governance, are insufficiently reflected in student cooperatives. This can ultimately weaken the development of students' cooperative identity and reduce their interest in starting or participating in a cooperative in adulthood.
\end{abstract}

Keywords: education, schools, student cooperatives, cooperatives, cooperative principles, cooperative identity

\section{SCHÜLERGENOSSENSCHAFTEN ALS BRUTSTÄTTE DES GENOSSENSCHAFTSGEDANKENS? REFLEKTIEREN DER GENOSSENSCHAFTSPRINZIPIEN IN DER TÄTIGKEIT VON SCHÜLERGENOSSENSCHAFTEN U IN KROATIEN}

\author{
Davorka Vidović
}

\section{Zusammenfassung}

Schülergenossenschaften sind ein Phänomen mit einer langen Tradition in Kroatien und seit 1950 sind sie auch als eine Art außerschulische Aktivität im Rahmen des Erziehungs- und Bildungssystems förmlich geregelt. In den letzten 15 Jahren steigt die Zahl von Schülergenossenschaften beträchtlich und heute gibt es 602 davon, d.h. fast jede zweite Schule hat eine Schülergenossenschaft gegründet. In der Arbeit werden Ergebnisse einer in den Jahren 2018 und 2019 durchgeführten Forschung über Schülergenossenschaften in Kroatien dargestellt. Die Forschung beruht auf einem explorativen Ansatz und einer qualitativen Methodologie, es wurden Interviews und ein Gruppenfokus am Muster von zehn Schülergenossenschaften eingesetzt. Als Konzeptrahmen benutzen wir in der Arbeit den Ansatz der Internationalen Genossenschaftsvereinigung (ICA), die bei der Bestimmung der "Genossenschaftsidentität“ die Definition, sieben Grundprinzipien und zehn Werte anführt. Der Zweck der Arbeit war es, festzustellen, auf welche Art und Weise die grundlegenden Genossenschaftsprinzipien in der Arbeit von Schülergenossenschaften angewandt werden und wie man sie als eine Art Brutstätte des Genossenschaftsgedankens betrachten kann. Die Forschungsergebnisse haben gezeigt, dass einige Prinzipien wie z.B. Ausbildung über Genossenschaftstum und demokratische Verwaltung sich zu wenig in der Arbeit von Schülergenossenschaften widerspiegeln. Letzten Endes kann das die Entfaltung der Genossenschaftsidentität bei Schülern beeinträchtigen und deren Interesse daran mindern, im Erwachsenenalter eine Genossenschaft zu gründen oder daran teilzunehmen.

Schlüsselwörter: Bildung, Schulen, Schülergenossenschaften, Genossenschaften, Genossenschaftsprinzipien, Genossenschaftsidentität 